\title{
Hail Incidence in the Tropics
}

\author{
E. M. FRISBY ${ }^{1}$ \\ Raven Industries, Inc., Sioux Falls, S. Dak. \\ AND H. W. SANSOM \\ East African Meteorological Department, Nairobi, Kenya
}

(Manuscript received 23 May 1966, in revised form 24 October 1966)

\begin{abstract}
This paper is a review and compilation of information concerning the incidence and frequency of hail fall in tropical areas. The authors have gathered the data over a period of years from literary sources and by extensive correspondence with private individuals and government meteorological services.

The four areas under which the various hail reports are grouped, viz., the American, African, Asian, and Australian, together form a total band around the Earth within latitudes $23 \frac{1}{2}$ degrees north and south of the equator.

Attempts have been made to systematize presentation of the information. This is possible only up to a point, however, since it was received in a multiplicity of forms, some of which defy conventional climatological handling.

Nevertheless, the paper makes possible for the first time a comprehensive assessment of the tropical hail phenomenon. Moreover, a great deal can be learned from it about seasonality of hail fall in specific areas and about the occurrence of hail at sea level and over the sea, facts which have been in question up to this time.
\end{abstract}

\section{Introduction}

Thus far, very little meteorological significance has been attached to the occurrence of hail in tropical latitudes. There is no question that the hail problem is a less serious one in the tropics than at mid-latitudes, both from the standpoint of frequency of incidence and hail size. Nevertheless, when hailstorms occur, they cause major damage to tobacco, tea, coffee, and other commercially grown crops. For this reason, quite apart from the purely meteorological one of curiosity with regard to an interesting natural phenomenon, they deserve some basic study.

It is generally recognized that far more hailstorms occur over hilly and mountainous terrain than at sea level. Cases of the latter exist, however, and this fact brings up the question of hail formation in the tropics, whether it is all of purely convective and orographic origin, or whether there are storms, at least on the fringes of the tropics, where middle-level winds play as important a role in hailstorm formation and behavior as they do in middle latitudes.

While this paper is a climatological one, dealing solely with the frequency and incidence of hail resulting from any storm type within the tropics, it is intended that it shall be followed by another, in which synoptic considerations will be the principal subject of discussion.

\footnotetext{
${ }^{1}$ Present affiliation: Atmospheric Sciences Labotatory, U. S. Army Electronics Command, Fort Monmouth, N. J.
}

\section{Review of past work}

After the general statements concerning hail in the tropics made by Visher (1922), Lemons (1942), Humphreys (1940), and Garbell (1947), and following the comments on the hailstorms of specific areas of the tropics made by Alexander (1903) for Puerto Rico, Selga (1929) for the Phillipines, Bougnol (1937) for French West Africa, Bultot (1959) for India, very little appeared in the literature on this subject until 1960 when the International Conference on Hailstorms was held in Verona, Italy.

At that conference, Sansom reviewed literary sources of tropical hail and went on to consider hailstorm distribution in East Africa (1961). His literature search was later supplemented by Frisby (1964) in an attempt to trace hailstorm behavior from the predominantly traveling storms of middle latitudes to the predominantly convective storms of the tropics. This investigation involved not only knowing in a broad sense where and when hailstorms occurred, but obtaining by correspondence the dates of specific hailstorms, so that they could be documented synoptically in sufficient detail for their type to be determined (Frisby, 1965). Meantime, Sansom was refining his estimates of hail occurrence in East Africa (1964), preparing a climatological hail estimate for the whole African continent (1965), ${ }^{2}$ and carrying on a voluminous correspondence with government meteorological departments throughout the

\footnotetext{
${ }^{2}$ Personal communication
} 
tropics in order that the tropical hail problem could be appraised in its entirety rather than piecemeal.

\section{Method}

Reports of hail received from government meteorological services and private individuals throughout the tropics took many forms. In some cases, as in India, where observations have been made over long periods of time, results were given reliably, as long-period monthly and annual means. In other cases, where the data have been assembled over short periods only, results were presentedias numbers of cases. In still other instances, where no routine records of hail have been kept, information: conceming an individual hailstorm was occasionally received. In several instances, e.g., Rhodesia, India, and Madagascar, numbers of hailstorms were quoted for areas rather than for individual climatic stations.

Thus, standardization in method of presentation is not possible at this time. This paper is perforce a compilation of available material rather than a comparative climatological study based on a long-period array of monthly and seasonal means.

It was agreed to limit the geographical scope of the investigation to the area between latitudes $23 \frac{1}{2} \mathrm{deg}$ north and south of the equator, and to present all relevant information, i.e., within the latitudinal limits quoted, in the form of notes and wherever possible, lists of means, or numbers of individual cases. The tables appear separately in Appendix 2.

Wherever known, coordinates and heights of stations are given, but these have not been found in every case,

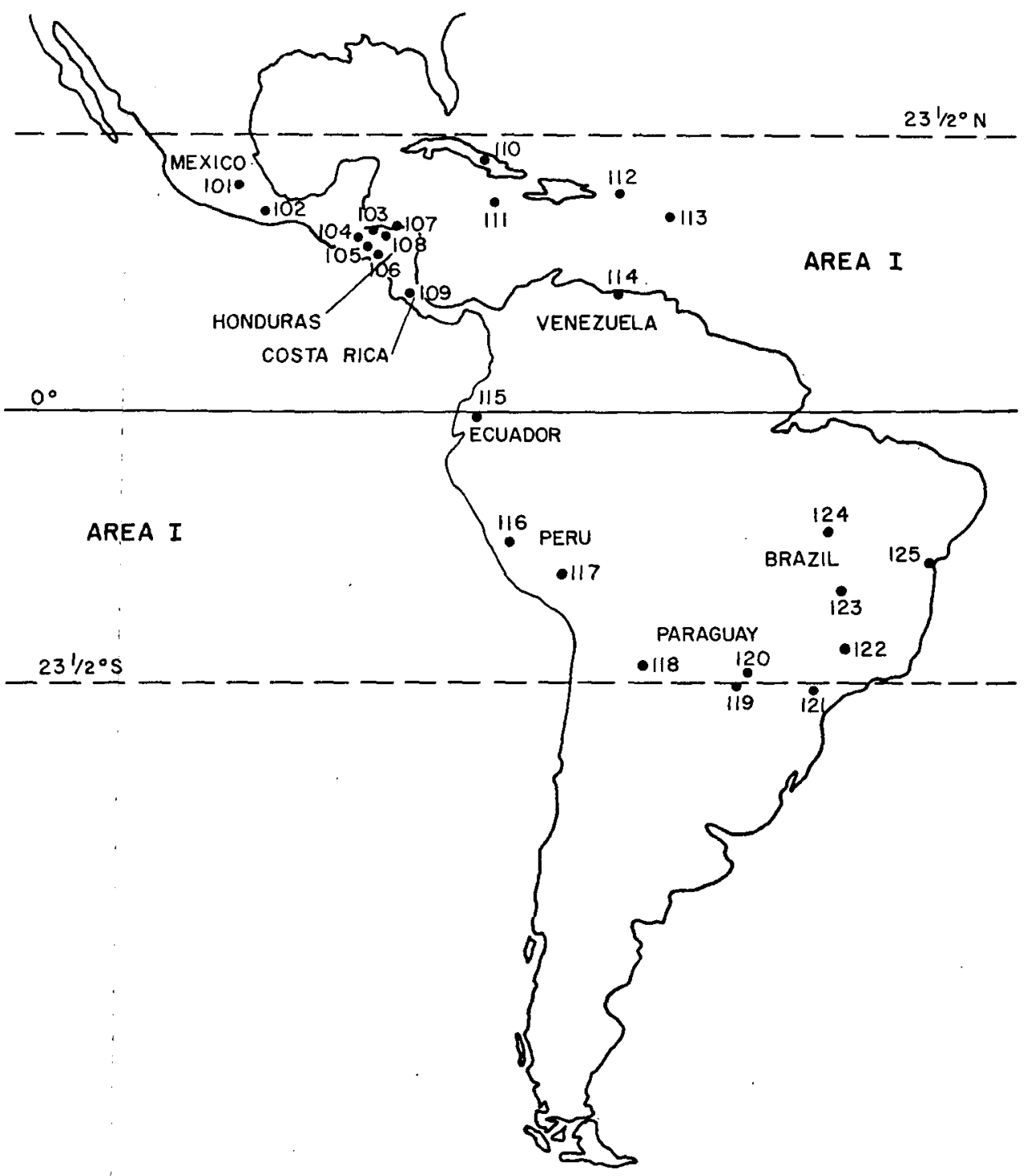

FIG. 1a. Representative hail reporting stations, area 1. 


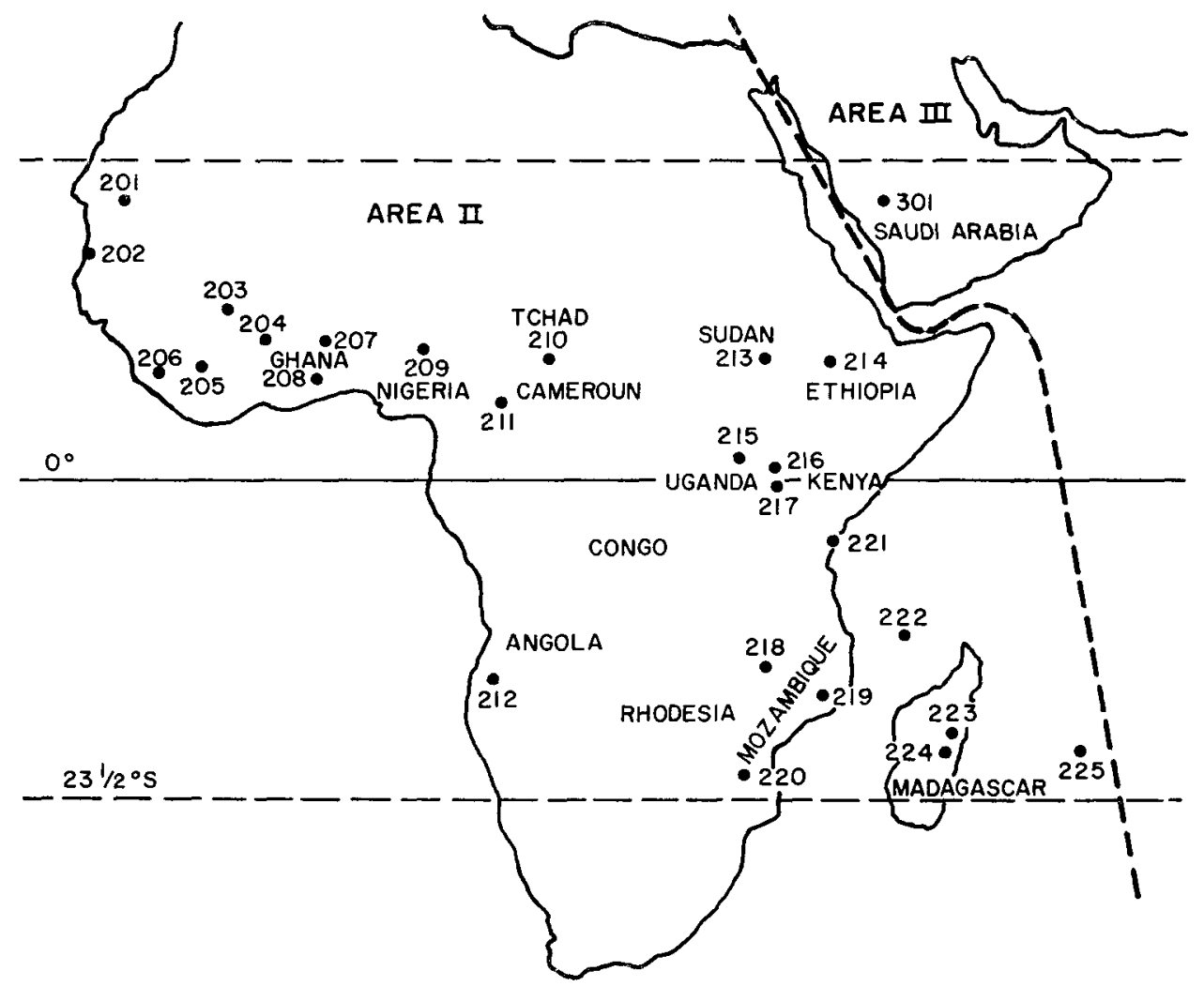

FIG. 1b. Representative hail reporting stations, area 2.

and many of the values are approximate. Length of record is shown arbitrarily as the first and last year in which hail was recorded.

Once the data had been sorted and listed, a map was prepared to give the general distribution of areas from which hail reports had been received (Figs. 1a, 1b, and 1c). In some cases, for example Brazil and India, numbers of reporting stations were so great that it would have been impracticable to try to put then all on a world map of the tropics. The places shown in Figs. $1 \mathrm{a}, 1 \mathrm{~b}$, and $1 \mathrm{c}$ therefore, are representative hailreporting stations in the hail areas of the countries to which they belong. Many are in mountainous areas inland, but an appreciable number are on sea coasts. A list of the reporting stations is given in Appendix 1.

In three instances it was found possible to give not only records from hail-reporting stations, but a climatological estimate of hail distribution by isolines, namely, for Africa (Sansom, 1965, personal communication), for India (Ramdas et al., 1938), and for Queensland, Australia (Queensland Meteorological Office, 1964, personal communication) (Figs. 2a and 2b).

Isolines for Paraguay have also been prepared by the Paraguayan Meteorological Service. But since the major hail area of that country is outside the tropics, they were not reproduced.

Casual study of the diagrams shows hail to be a feature of the entire tropical area, with the possible exception of equatorial Brazil, Malaya, and Indonesia. But it seems likely that when systematic observations are made, hail will be found to occur in these regions also. A recent report of a hailstorm on the coast at Kuching, Sarawak (Stemmler and Stephenson, 1965) lends substance to this idea.

\section{Discussion}

Area No. 1. Hail in the Caribbean, Mexico, Central and South America. Data for this part of the study were received from Cuba, Puerto Rico, St. Kitts, Barbados, Jamaica, Mexico, Costa Rico, Honduras, Venezuela, Argentina, Brazil, Paraguay, Ecuador, and Peru. The following listings combine both tables and notes.

1) Cuba. "Hailstorms are so rare in Cuba that no special study of this phenomenon has been made. However, one case is known to have occurred. On 29 March 1963, a hailstorm struck Victoria de las Tunas $\left(20^{\circ} 58^{\prime} \mathrm{N}, 76^{\circ} 57^{\prime} \mathrm{W}\right)$. It extended over an area $3 \mathrm{~km}$ to the south, $1.5 \mathrm{~km}$ to the north, $10 \mathrm{~km}$ to the east, and $71.3 \mathrm{~km}$ to the west. Hail began at 1500 and ended at 1518 local time. Altogether, $47.7 \mathrm{~mm}$ of rain and melted hail were recorded. The storm was accompanied by winds of 75 to $85 \mathrm{~km}$ per hour. Trees were uprooted, roofs destroyed or torn off houses, and holes punched even in zinc roofs. In places, hailstones were two feet deep. 


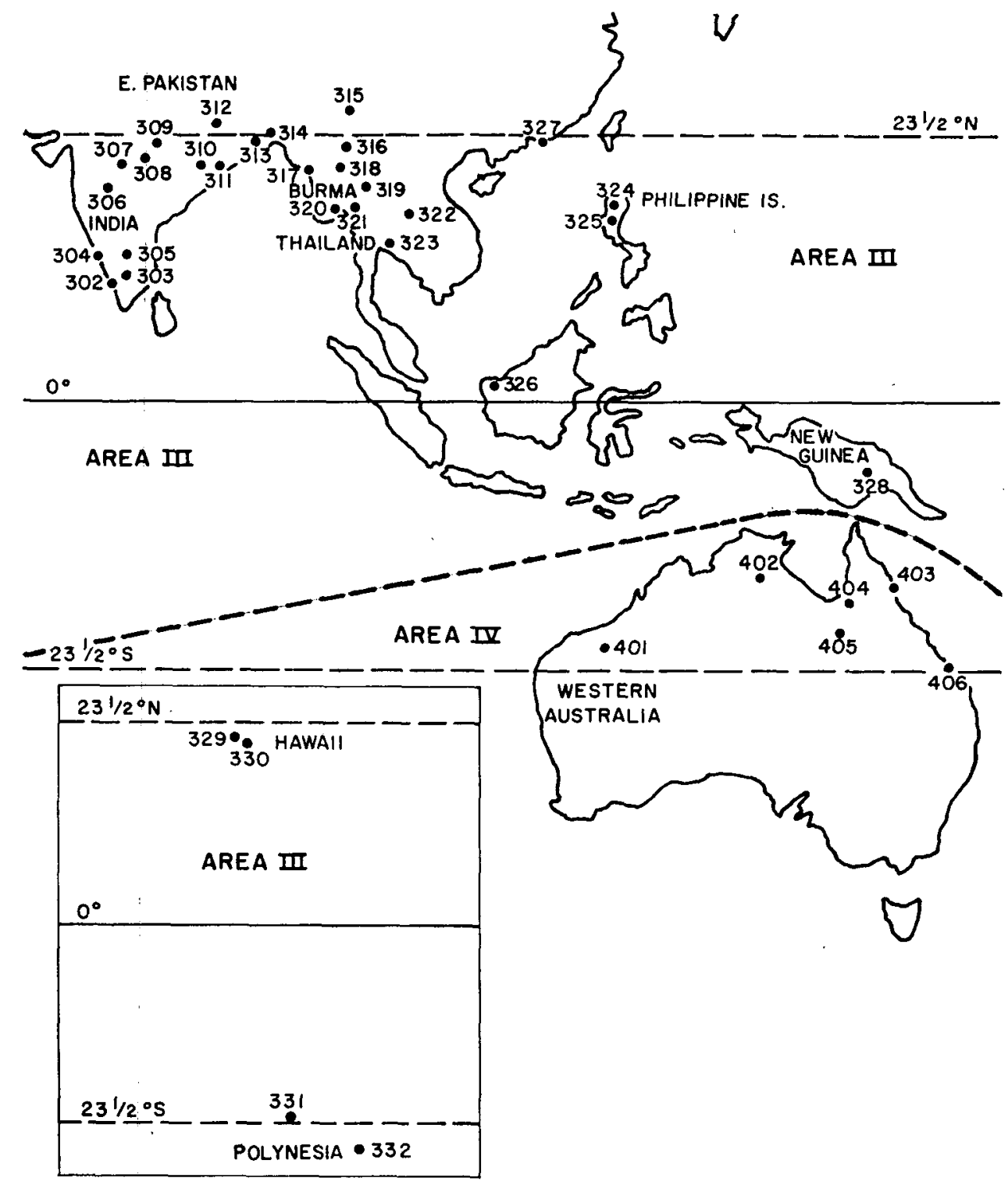

FIG. 1c. Representative hail reporting stations, areas 3 and 4 .

Individual stones were about $3.7 \mathrm{~mm}$ in diameter." Director del Observatorio Nacional.

2) Puerto Rico. Well-documented hailstorms occurred on this island on 12 May 1905, 13 May 1905, 6 May 1926, 29 September 1955, 12 February 1957, 8 November 1963 and 24 December 1965. All but the last of these have already been discussed in an earlier publication (Frisby, 1965).

3) St. Kitts. An extremely interesting case of hail falling at sea level occurred on this island on 24 November 1963. This storm was also discussed in an earlier publication (Frisby, 1965).

4) Barbados. A hailstorm was reported on this island in December 1965. Supporting documentary data have been promised but not yet received.
5) Jamaica. A note from Kingston reports, "The fall of hail is not of frequent occurrence in Jamaica, and it has not been very destructive, with the exception of one or two storms affecting cultivation within a limited area. During a period of ten years there were 35 places reporting, in the aggregate, the fall of hailstones. The largest percentage appears to be confined to the month of May, when there is a preponderance of cirrus or cirrostratus clouds beginning to develop, and a very few reported in April, October, and November. On the whole nearly all seem to occur in parishes to the westward of Kingston, and practically none to the eastward." Divisional Assistant Director. (Table 1, No. 5).

6) Mexico. A very large number of stations have reported experiencing hail. Only those with an annual 
average of four hail days or more were selected for tabulation. (Table 1, No. 6).

7) Costa Rica. A well-marked hail season between April and September is evident from the Costa Rica data. (Table 1, No. 7).

8) Honduras. April to October is the main hail season in Honduras. (Table 1, No. 8).

9) Venezuela. The following notes were received from Venezuela:

"September 18, 1954. Hail fell in Caracas for about three minutes during an afternoon storm. Hailstones were of the size of kernels of corn.

"June 25, 1955. Severe hail fell in Valera. It was 40 $\mathrm{cm}$ deep in Saijita, and many orchards were destroyed. The hailstones were large enough to kill hens and turkeys and harm human beings. Twenty houses were destroyed and branches were torn from trees.

"September 6, 1955. Another bad hailstorm in Carora caused heavy loss.

"September 24, 25, and 26, 1955. The cultivated fields of Galipan in la Flada del Avila were whipped by the strong winds of a hailstorm. 'Days of the passage of Hurricane Janet.'
"April 28, 1956. A storm accompanied by hail and lightning, which lasted for about half an hour, hit Tariba and Palmira.

"November 25, 1956. A bad hailstorm occurred in Tucasas.

"May 20, 1957. A hailstorm hit the las Tejerlas area with winds of hurricane force.

"April 18, 1958. Hailstorms occurred over Los Teques.

"July 20, 1962. Hail fell over Carora.

"October 9, 1963. Hail fell on Cumanacoa quay for several minutes."

10) Argentina. Very little of Argentina is inside the tropics, but the record for La Quiaca shows the hail season to be mainly spring and summer. (Table 1, No. 10).

11) Brazil. Oniy those records showing eight or more hailstorms in 18 years have been tabulated. It is significant that all reports are from the southeast of the Republic, none from the Amazon Valley itself. In addition to the report received from the Brazil Meteorological Service, however, the following information has just been received from Dr. H. Sioli in Plon, Germany:

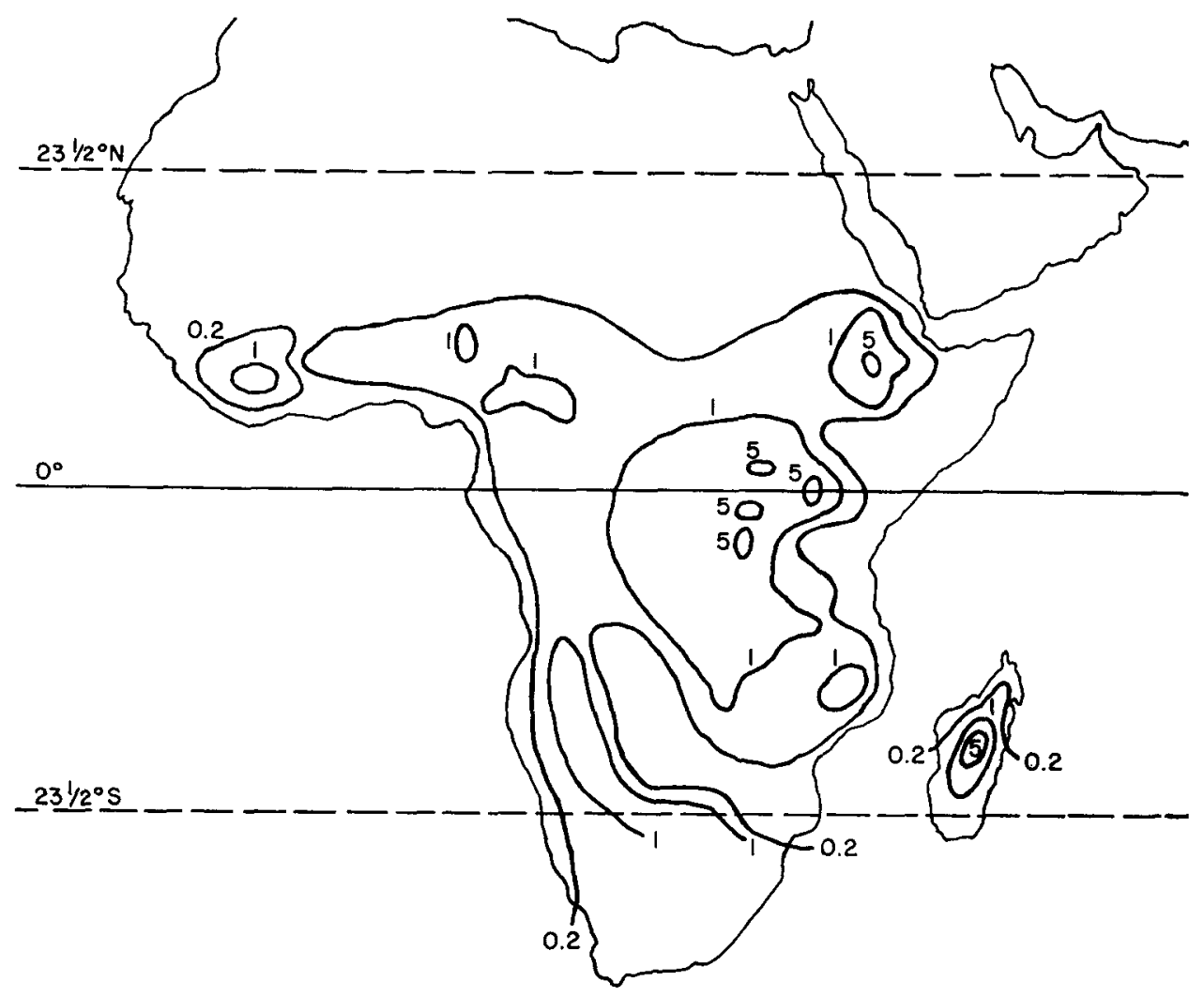

MEAN ANNUAL FREQUENCY OF HAIL OVER AFRICA (1O YEAR RECORD)

FIG. 2a. Hailstorm distribution for Africa. 


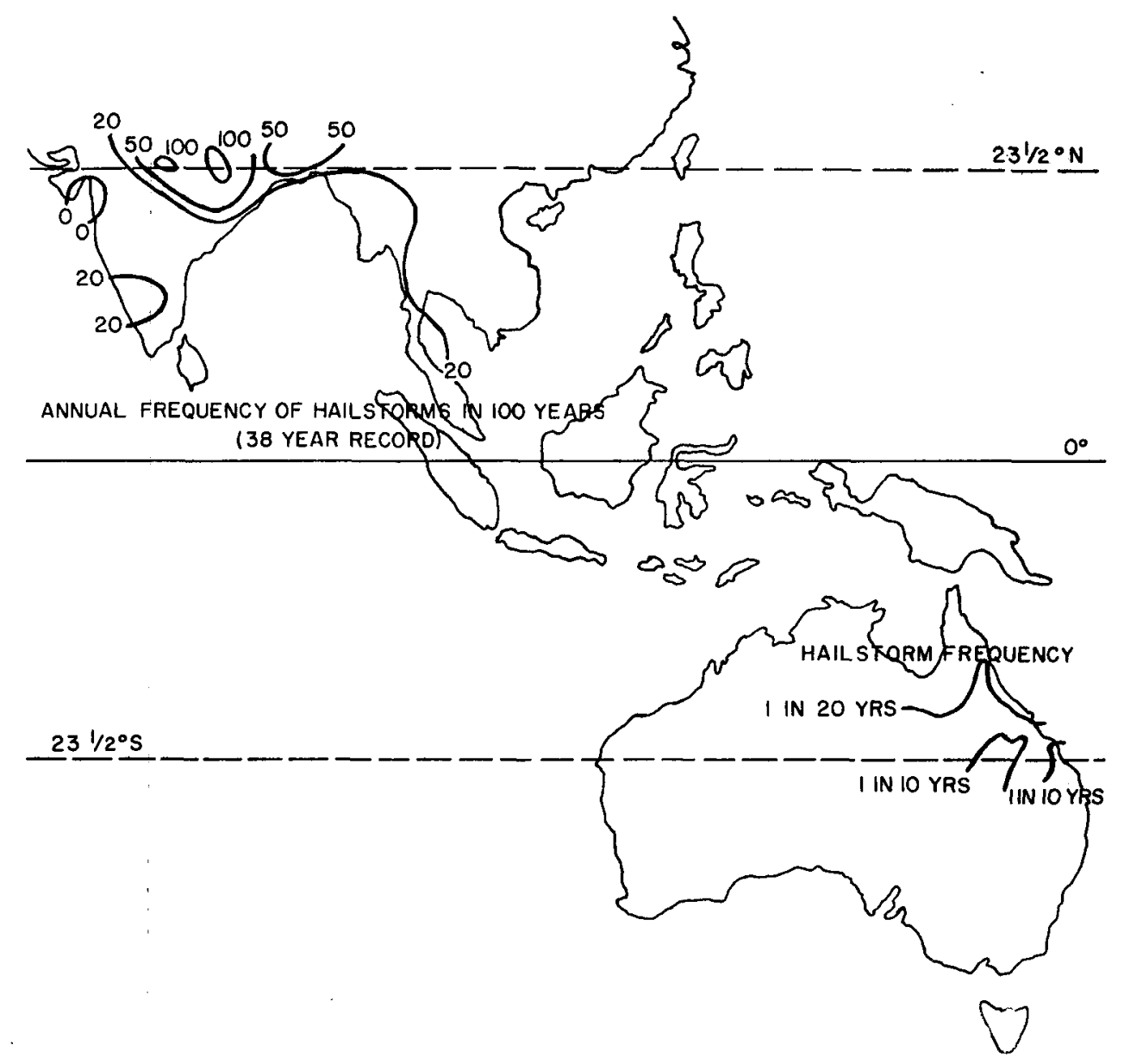

FIG. 2b. Hailstorm distribution for India and northeast Australia.

"I heard that once hail had fallen at the small city of Obidos, on the northern shore of the lower Amazon. But I do not know when it happened, and how this hail was.

"I myself, observed hail on the Rio Cururu, a confluent of the upper Rio Tapajos, $7 \frac{1}{2} \mathrm{~S}$ and $57 \frac{1}{2} \mathrm{~W}$. It was a short shower of hail, but the hailstones were perhaps a bit greater than half a centimeter in diameter.

"That is all I can inform you of hail in the Amazon region. I do not know of any record which has been kept about this phenomenon." (Table 1, No. 11).

12) Paraguay. As was noted earlier in this report, few Paraguayan stations fall within the tropics. Those that do or are close to $23 \frac{1}{2} \mathrm{~S}$ are listed in Table 1 , No. 12 .

13) Ecuador. Hail-reporting stations within the tropics in Ecuador are close to the equator, but all are very high. (Table 1 , No. 13).

14) Peru. Hail reported in Peru is also at high stations in spring, summer and fall. (Table 1, No. 14).

Area No. 2. Hail in Africa, including the Indian Ocean Islands. Although hail is extremely rare on the coast of tropical Africa, most inland places, including those at quite low elevations, have occasionally reported hail.
The greatest incidence of hail occurs on the high ground in western Kenya, in western Uganda, Rwanda and Burundi, where the mean frequency exceeds five hailstorms a year. A generalized map of the mean annual frequency over tropical Africa is shown in Figs. $2 a$ and $2 b$. Data have been received from almost all countries in Africa, in varied forms. Published sources which have been used are those of Bougnol (1937) for the former French West Africa, Bultot (1959) for the former Belgium trust territory of Ruanda-Urundi (now Rwanda and Burundi) and the Congo, and Sansom (1961) for East Africa.

1) Mauretania. According to Bougnol (1937), hail is very rare except at $A \operatorname{tar}(21 \mathrm{~N}, 13 \mathrm{~W})$ in the interior.

2) Senegal. There have been no reports of hail during the past 30 years, but Bougnol mentions a hailstorm at Saint Louis (approximately 16N) on the coast, on 9 October 1934, when hail of an average diameter of $10 \mathrm{~mm}$ fell for $4 \mathrm{~min}$.

3) Guinea. The only available information is from Bougnol (1937): "There are frequent hailstorms, especially in the mountainous triangular area comprising Kindia-Siguira-Mali. Hail occurs frequently in the 
Beyla area also $\left(8 \frac{1}{2} \mathrm{~N}, 8 \frac{1}{2} \mathrm{~W}\right)$. It occurs rather less often in the Kissidougou (9N, 10W) and is rare elsewhere."

4) Sierra Leone. The meteorological station at Daru $(8 \mathrm{~N}, 11 \mathrm{~W})$ has reported hail three times in the past five years, and Kabala $\left(9 \frac{1}{2} \mathrm{~N}, 10 \frac{1}{2} \mathrm{~W}\right)$ twice in the past ten years.

5) Ivory Coast. "Hailstorms are very rare on the Ivory Coast, and very exceptional along the Atlantic Coast. North of latitude $6 \mathrm{~N}$, there are an average of $1 \frac{1}{2}$ hailstorms per year; along the coast only one in four years." Representant de L'Asecna en Cote d'Tvoire.

6) Mali. According to Bougnol (describing the former French Sudan, which is now Mali), hail is rare except in the region of Faladie (13N, 8W) "where meteorological conditions seem to be peculiar (nine cases in four years)." A more recent communication (December 1964) states: "Indeed, to my knowledge, this phenomenon has been observed only at Sikasso $(11 \mathrm{~N}, 6 \mathrm{~W})$ and on the following dates: 2 May 1952, 27 July 1953 (between 1850Z and 1855Z), and 13 February 1953 (between 1735Z and 1838Z)." Chef de la Division de la Meteorologie du Mali.

7) Upper Volta. Three places, Ougadougou $\left(12 \frac{1}{2} \mathrm{~N}\right.$, $\left.1 \frac{1}{2} \mathrm{~W}\right)$, Bobo-Dioulasso (11N, $\left.4 \mathrm{~W}\right)$, and Ouahigouya $\left(13 \frac{1}{2} \mathrm{~N}, 2 \frac{1}{2} \mathrm{~W}\right)$ have reported three storms in ten years. The average diameter of the hail is 7 to $10 \mathrm{~mm}$, and the storms occurred during violent thunderstorms associated with line squalls. The duration of the hailstorms was from 2 to $7 \mathrm{~min}$.

8) Ghana. Reports of hail are very infrequent, but Ho $\left(7 \mathrm{~N}, 0 \frac{1}{2} \mathrm{E}\right)$ at an elevation of about $150 \mathrm{~m}$ above mean sea level quite near the coast, recorded three storms in a single year, 1950. (Table 2, No. 8).

9) Togo. "Hailstorms are of very short duration and occur chiefly in the mountainous regions of the southwest and northeast. They occur at the beginning of the rainy season (between noon and 1800 hours). In the southwest this means in February, March, and April; in the northeast in June. Hail is associated with topographical storms in areas where convection is strongest. However, hailstones are not large, storms do not last long, and melting takes place as soon as the stones reach the ground." Le Representant de L'Asecna au Togo.

10) Dahomey. At Natitingou (10N, $1 \frac{1}{2} \mathrm{E}$ ), approximately $500 \mathrm{~m}$ above mean sea level, there were ten reports of hail in the 25 years 1940-1964; Kandi (11N, $3 \mathrm{E}$ ), approximately $300 \mathrm{~m}$, has six reports in the same period, and Bohicon ( $7 \mathrm{~N}, 2 \mathrm{E})$ five. Cotonou $\left(6 \frac{1}{2} \mathrm{~N}\right.$, $2 \frac{1}{2} \mathrm{E}$ ) on the coast has not reported any hail in 25 years.

11) Nigeria. Hail is fairly frequent at Jos $(10 \mathrm{~N}, 9 \mathrm{E})$ in the interior, where 33 hailstorms were reported in ten years. But even nearer the coast, hail occurs occasionally. At Ibadan ( $7.5 \mathrm{~N}, 4 \mathrm{E}), 230 \mathrm{~m}$ above mean sea level, there is an account (Hopkins, 1962) of ellipsoidal hailstones over $1 \mathrm{~cm}$ in length which fell on 16 April 1962. (Table 2, No. 11).
12) Cameroun. Data for 10 years indicate that a number of places average one storm a year, with Meiganga $\left(6 \frac{1}{2} \mathrm{~N}, 14 \mathrm{E}\right)$ recording 23 storms in the 10 year period. (Table 2, No. 12).

13) Gabon. "Hailstorms are very rare in Gabon and practically nonexistant along its coasts. The number of times that hail has been observed, at certain inland stations over a period of five years, is at most 2 or $3 . "$ Le Chef du Service Meteorologique de Gabon.

14) Angola. Annual frequencies are everywhere less than one a year, and in over 20 years of records there are no reports of hail on the coast. Even at high elevations, hail frequencies are surprisingly low. (Table 2, No. 14).

15) Tchad. "Please find herewith a tabulation of hailstorms observed at the 12 synoptic stations in Tchad. To my knowledge there are no published descriptions of hailstorms. I, myself, saw one storm that occurred at Fort-Archambault in 1958. A number of hailstones in that storm weighed as much as $50 \mathrm{gm}$. One of these caused the death of a passing African." La Chef du Service Meteorologique. (Table 2, No. 15).

16) Central African Republic. "Hailstorms are extremely rare in the Central African Republic and for this reason have not been made the subject of special study." La Chef de l'Exploitation Meteorologique.

17) Congo (Leopoldville). In Kivu Province, west and north of Lake Kivu, hail frequencies in excess of five storms a year are reported (up to nine storms a year north of the lake). The highest monthly frequencies occur in the months September to March, with the peak in February. Up to two storms a year also occur in sou thwest Katanga Province during the same months, but with the peak in October. Bultot (1959).

18) Rrvanda and Burundi. Bultot (1959) has reported hail frequencies in excess of five storms a year near the western borders (east of Lakes Kivu and Tanganyika), particularly during the months of September to March (peak frequency in February).

19) Sudan. "Reliable records of hail frequency have not been kept for a sufficiently representative number of stations to cover the country over a sufficiently long period. But from the study of the limited record available, it would seem that hail is generally not very common in the Sudan, and that the frequency of the hail that does fall decreases from south to north. Generally speaking, it may be safely assumed that in the Southern Sudan to about 10N, hail falls once or twice in 5 to 7 years; between $10 \mathrm{~N}$ and $13 \mathrm{~N}$, once in 7 to 10 years; and between $13 \mathrm{~N}$ and $17 \mathrm{~N}$, once in 10 to 15 years.

"Hail is extremely rare north of $17 \mathrm{~N}$, and not a single observation has been reported in the last 30 years or so. However, in mountainous areas such as the Murra Mountains, the southern Nuba Mountains (around Talodi town) and in the southern Fung District near the Ethiopian border, the frequency of hail may be once or twice in 3 to 5 years. 
"The familiar form is generally soft hail with the hard core about the size of a pea or pellet; but under intense convection, the size may exceed slightly that of a marble. Yet our relatively short record includes mention of a freak storm at Daga Post $\left(9^{\circ} 12^{\prime} \mathrm{N}\right.$, $33^{\circ} 58^{\prime} \mathrm{E}$ ) on April 20,1954, in which it was claimed that the hailstones were the size of a man's fist and weighed about five rotls $(2-1 / 4 \mathrm{~kg}$ each).

"The story was disbelieved at the time and its authenticity queried, but the District Commissioner, Nasir $\left(08^{\circ} 37^{\prime} \mathrm{N}, 33^{\circ} 04^{\prime} \mathrm{E}\right)$, who conveyed it, was emphatic. The following gives his full description of the strange phenomenon:

"You will note that on 20 April 1954 there was a freak storm. Hail fell for about half an hour and covered the ground to a depth of about 18 inches. It is reported that the hailstones were the size of a man's fist and weighed about five rotls each. Considerable damage was done to the houses of the natives.'

"I would like to add that on the average the amourit of 'liquid' rain associated with hail is small, seldom exceeding $5 \mathrm{~mm}$, except in very severe hailstorms. The storm was stated to have occurred at Daga on 20 April 1954. It gave $24 \mathrm{~mm}$ of associated rain." Government Meteorologist.

20) Ethiopia. Hail is fairly frequent during the second half of the rain season, June to September. (Table 2, No. 20).

21) French Somaliland. "In 60 years of observation, there has never been a hailstorm in Djibouti. But in the higher zone, north of the French Coast of Somaliland, there have been several hailstorms during the general storm period (end of July, August, and September). The intermittent observational record made at Randa $\left(11^{\circ} 51^{\prime} \mathrm{N}, 42^{\circ} 39^{\prime} \mathrm{E}\right)$, altitude $920 \mathrm{~m}$, since 1948 , shows hail to have occurred on 20 September 1948, 24 September 1955, and 11 September 1965." Service Meteorologique.

22) Somalia. "I have not complete data avaiiable in hand at present. However, I can inform you that hail sometimes occurs in the northem region of Somalia in the first rain season, usually in June and July. Hargeisa Meteorological Station reported sometimes during these two months thunderstorms, moderate with hail which last usually 20 to 30 min." Senior Meteorological Officer.

23) Kenya. This has been the subject of detailed studies by Sansom (1961, 1964, and 1965). Although there is one place (Makamini) near the coast where hail is alleged to occur regularly, the main hail area is on the high ground east of Lake Victoria, where fall frequencies of 5 to 10 a year are not uncommon. This hail belt extends from Mount Elgon in the north, through the Nandi Hills, to Kericho and Kisii in the south. The number of days on which hail is reported in the area is well over 100 , with over 50 days a year at Kericho alone (Table 2, No. 23).
A more detailed temporary hail-reporting scheme introduced during August and September 1965 indicated that hail was reported on 51 out of 61 days during these two months. It therefore seems probable that a high proportion of thunderstorms in this area contain some hail.

Although the sizes of hailstones normally reported are quite small (generally below $1 \mathrm{~cm}$ diameter), hailstones of diameter greater than $2.5 \mathrm{~cm}$ are not uncommon, and golf-ball-size stones are occasionally reported.

24) Uganda. Hail is occasionally reported in thunderstorms around the northwestern shores of Lake Victoria, and no part of Uganda is entirely free from hail; the highest frequency occurs in Toro, near the Ruwenzori Mountains, where the point frequency is between 5 and 10 a year. Hail occurs mainly during the months of September and October and January to March.

25) Tanzania. Apart from occasional reports of hail near Lake Victoria, including Ukerewe Island, the region north of Lake Nyasa and the Southern Highlands, hail is fairly rare in Tanganyika. There have been no records of hail on the coast or on Zanzibar.

26) Mozambique. Hail has been reported from almost all parts, including the coast, but the higher frequencies occur a little way inland. (Table 2, No. 26).

27) Rhodesia. A detailed statistical analysis has been made by degree squares, which indicates that "on watershed areas the number of hail reports received annually amounts to some 20-25 per cent of the total number of stations, i.e., one occurrence in 4 or 5 years for any individual station. Allowing for hail occurrence not reported, the frequency may be something like 1 in 3 years. The frequency decreases on lower ground to about 8 per cent, i. e., once in 12 years. Allowing for a greater number of occurrences unreported since settlement is sparser, the frequency may be of the order of 1 in 6 years, i.e., about half that on higher ground." Director, Meteorological Department. (The records shown in Table 2, No. 27, indicate the existence of a hail season from September to January, with a peak in November.)

28) Seychelles. There is no record of hail falling anywhere on the Seychelles Islands. Although the rainfall is high, the average incidence of thunder is only 20 days a year.

29) Madagascar. Hail occasionally occurs on the coast, particularly in the Mozambique Channel area, but it is common over the high ground of the interior, reaching an average of over five storms a year around Antsirabe, south of Tananarive (Fig. 2). Hail has occasionally been reported on the Grande Comore Island $\left(11 \frac{1}{2} \mathrm{~S}, 43 \mathrm{E}\right)$ in the north of the Mozambique Channel, but there are no reports of hail in a 10-year period at Diego Suarez on the northern tip of the mainland. (See Table 2, No. 29, for seasonal distribution.)

30) Mauritius. There have been five reports of hail, including one of "grape size" and one of "hazelnut 
size" stones, at Mauritius during the last 100 years. Four of the reports are, however, in the last 15 years. There is an interesting account of a hailstorm over the sea in 1953 (exact data unfortunately not known):

"About one quarter mile off northwest coast of Mauritius. Witnessed and reported by professional accountant who was out fishing. Hailstones about the size of grapes fell for about one minute with such violence that the witness had to take cover." Director of Meteorological Services.

Area No. 3. Hail in Arabia, India, Indonesia, Southeast Asia and the Pacific Islands. Information from this area is even more varied than that from Areas 1 and 2. Tables and notes on individual countries and stations are listed as follows:

1) Saudi Arabia. Only one hail report was received from tropical Arabia, namely that for Taif in July 1962. The following note, however, will serve as supplementry information. "Enclosed you find information about hail occurrence in Saudi Arabia. I must, however, emphasize that this is the official record. Since most of the area subjected to hail is reported on by news media, aircraft or the like, and does not have any meteorological station the hail does not get included in the official record. Hence, I will tend to suggest that the data enclosed is a bit underestimated." Director, Meteorological Service.

2) India and Pakistan. Remarkably detailed data are available for these areas (Ramdas et al., 1938; Khan and Abbasi3 ${ }^{3}$, 1965). However, since Western Pakistan falls outside the tropics, and since West and East Pakistan are included in the 38-year annual distribution map of hailstorms prepared by Ramdas in 1938, his diagram is the one used in Figs. 2a and 2b. Additional reason for this decision was found in the fact that Khan and Abbasi's annual distribution map for Pakistan, based on only 10 years of data, appeared to be considerably different from the one based on the longer record. Relatively recent data for both India and Pakistan are shown in Table 3, No. 2a (India) and No. 2b (East Pakistan).

3) Burma. Stations reporting hail in tropical Burma are mostly in the hill country. But Tharawaddy in the Irrawaddy delta area is an exception to this rule and apparently experiences hailstorms in the fall, whereas the more northerly areas experience them in spring and summer. (Table 3, No. 3).

4) Ceylon. "There is no prepared data for Ceylon on occurrence of hailstorms. Hail is reported in Ceylon about once or twice almost every year, generally during the intermonsoon months of April, May, October, and November. Local convection gives rise to cumulonimbus and thunderstorms, and the reports always state that there was severe lightning and thunder, and that

${ }^{3}$ A survey of hailstorms in Pakistan. Karachi unpublished manuscript. pieces of ice then fell out of the sky.' Director, Meteorological Department Colombo.

5) Thailand. Hailstorms are a spring phenomenon in Thailand, with a peak in March and April. (Table 3, No. 5).

6) Vietnam. "In reply to your letter EAMC/ $1464 / 2$ dated 30 November 1964, I have the honour to inform you that hail observations are rare in Vietnam. This meteorological station is signaled three times or so per year during the hot season in mountainous areas." Director of Meteorological Services of Vietnam.

7) Hong Kong. "Hail is exceedingly rare in Hong Kong and consequently there are no monthly summaries. Since 1883 there has been only one authenticated case of hail in the Colony. This event is described by Heywood in the Hong Kong Naturalist, August 1940, p. 105:

\begin{tabular}{|c|c|}
\hline Date of storm & 4 March 1940 \\
\hline Time & 0630 hours local time \\
\hline Hail size & $\begin{array}{l}\text { Stones with largest } \\
\text { diameter, } 1^{\frac{1}{4}}{ }^{\prime \prime}\end{array}$ \\
\hline $\begin{array}{l}\text { Surface temperature at } \\
\text { the time }\end{array}$ & $63 \mathrm{~F}$ \\
\hline $\begin{array}{l}\text { Freezing level from air- } \\
\text { craft sounding }\end{array}$ & $12,000 \mathrm{ft}$ \\
\hline
\end{tabular}

Severe thunderstorms in spring and autumn infrequently yield raindrops with a slushy center. Such a case occurred on Saturday last, 17 October 1964. Details of the situation can be provided if required.

"In the last 15 years there has been only one report of hailstones at ground level. The occasion was in the spring and no details are available.

"The freezing level is lowest in the months of January and February $(4330 \mathrm{~m}$ ) and has been as low as $2330 \mathrm{~m}$ (14 January 1963) during the last 15 years. Inland, the air temperature at the surface falls to below $0 \mathrm{C}$ a few times each year, but the air is much warmer aloft.

"The wind shear is normally greatest in February when the climatological monthly mean wind at $11 \mathrm{~km}$ is $260 \mathrm{deg} 80 \mathrm{kt}$, and the $500-\mathrm{m}$ wind is $085 \mathrm{deg}, 6 \mathrm{kt}$." Director, Royal Observatory.

8) Kuching, Sarazvak. A telling couple of paragraphs from Stemmler and Stephenson (1965) are as follows: "At 1515 hours, heavy rain commenced at the airfield and visibility fell to about 500 yards. Ten minutes later, the precipitation turned to hail, which lasted about half a minute. Mr. Benedict Chin, the Meteorological Supervisor of the Sarawak Department of Civil Aviation, picked up some of the hail which melted very rapidly. It was estimated to be about $\frac{3}{8}$ inch in diameter and was composed almost entirely of clear ice. (Hailstorm of 22 September 1964).

"In conclusion it is interesting to speculate as to whether this occurrence of hail at a low altitude close to the equator was in fact as unique as the evidence appears to indicate. Rainfall in equatorial storms is 
often so heavy that the presence of hail could go undetected, both aurally and visually, and it may be that in this case only the presence of an alert observer in the right place and at the right time resulted in its being reported."

9) Phillipine Islands. "With reference to your letter $\mathrm{EAMF} / 1464 / 2$ of October 12 , requesting data on hailstorms in this country, we are furnishing you the following information:

"There have been cases of hailstorms reported at high elevations, especially over the mountain area. In the lowlands, hail has also been reported to have fallen, associated with well-developed thunderstorms. The hailstones, however, melted upon striking the ground.

"The monthly frequencies of hail in the Phillipines cannot be established as this phenomenon 'is a rather rare occurrence."' Director Selga (1929), however, suggests that most hailstorms occur in March, April and May.

10) New Guinea. A few reports of hail have been received from $\mathrm{Mt}$. Hagen in this area. (Table 3, No. 10.)

11) New Caledonia. "I have the honor to inform you that hail is so infrequent in our area that statistics of its occurrence have not been kept. Indeed, no instance of hail has been recorded at any meteorological station in the Territory.

"During the last 15 years, very heavy precipitation has been brought to our notice several times. Its intensity has been too great to be measured. As far as frequency is concerned, one has to allow that at least one hailstorm occurs each year somewhere in the territory, generally in the mountainous section, which is practically uninhabited." Ingenieur en Chef de la Meteorologie.

12) Polynesia. "With reference to your letter, I am honored to inform you that hail incidence in Polynesia is extremely rare. Indeed, for the period 1937 through 1963, only the following cases were observed: 6 July 1952 (night of 5th and 6th), Rapa Island, 3-mm diameter hailstones; 13 and 27 May 1965 (midnight), Rurutu Island, 5-mm diameter hailstones." Chef de Service.

13) Hawaii. A note in "Local Climatological Data" (U. S. Weather Bureau) for General Lyman Field, Hawaii, March 1964 states, "On March 20, hail $\frac{1}{4}$ inch in diameter fell over the city of Hilo between 1530 and $1550 \mathrm{~A}$. This is believed to be the first hailstorm ever to reach the downtown area."

Information about another hailstorm that occurred in Hawaii on 4 February 1965 has also been received. A UPI account is as follows: "A torrential rainstorm struck Oahy Island on Thursday. It moved in from the Pacific amid thunder, lightning, and heavy hail, the latter extremely rare in this semitropical climate." Meteorological documentation has not yet been received for either storm.

Area 4. Hail in Australia. Reports of hail in tropical Australia are found principally in Northern Queensland.
The isoline diagram shown in Figs. $2 \mathrm{a}$ and $2 \mathrm{~b}$ is based on 20 years of press reports. To quote the Queensland Regional Meteorological Office: "It gives the correct distribution of hail throughout the state, with the highest frequencies over the highlands in the southeast, decreasing quite noticeably in the tropics. The northward bulge in the 'once in 20 years' isoline covers the Atherton tableland region, an area of mean elevation about $2000 \mathrm{ft}$. A few isolated instances of hail have been reported north of this line, for example, at Cairns on the coast and Croydon in the Gulf country, but they represent a very rare type of event."

Complete documentation has been received for one severe hailstorm that occurred in the Rockhampton area on the fringe of the tropics in October 1964.

\section{Conclusions}

It is evident that topographical and other features play an important part in hail occurrence at low latitudes; there are some localities where hail evidently occurs fairly frequently even at low elevations, whereas there are others in the same general meteorological regime where hail is apparently rare, even at much higher elevations. The qualifying adverb "apparently" is used advisedly, since because of its relative rarity, hail is a meteorological phenomenon that has received only casual scrutiny in the past. Stemmler and Stephenson's comment on hail fall and its observation at the equator, following the September 1964 hailstorm at Sarawak (1965), is considered most apposite by the present authors.

In this connection, it is gratifying to find that the Environmental Science Services Administration has recently requested all meteorological observers in the Caribbean to report hail as well as thunderstorms and rain. Extended use of this practice would probably bring many interesting facts to light in a relatively short space of time.

In spite of the fact that the records used in this report were received in many forms, and were in some cases incomplete and in others of incorrect magnitude, some interesting facts can be learned from most of them, if only with regard to the timing of the hail season in each area.

In the last three years, Frisby (1965) has attempted to document and reconstruct a few specific low-latitude hailstorms. As a corollary to the data compiled in this report, the number of documented examples should be increased and the study of individual storms intensified. Such a project would be an invaluable adjunct to any program of cloud modification in the tropics.

Acknowledgments. Both authors wish to express grateful thanks to all agencies and individuals who have in any way contributed to this world-wide tropical project and especially to the United States Army Atmospheric Sciences Laboratory and the East African Meteorological Department, without whose sponsorship 
and interest it would not have been possible. Data extracted from official files of the East African Meteorological Department are published by kind permission of the Director.

APPENDIX 1

Area 1
101 Tacubaya
102 Tlaxiaco
103 Tela
104 Santa Rosa
105 Toncontin
106 Ampala
107 Guanija
108 Catacamas
109 El Coco
110 Victoria de las Tunas
111 Kingston
112 San Juan
111 St. Kitts
114 Caracas
115 Quito
116 Pachachaca
117 Chuquibambilla
118 La Quiaca
119 Honqueta
120 Pedro J. Caballero
121 Itepeva
122 Santo Rito
123 Formosa

124 Porto Nacional 125 Santo Antonio de Jesus

$$
\text { Area } 2
$$

201 Atar

202 St. Louis

203 Faladie

204 Sikasso

205 Beyla

206 Daru

207 Natitingou

208 Ho

209 Jos

210 Fort Archambault

211 Meiganga

212 Sa da Bandeira

213 Daga Post

214 Addis Ababa

215 Toro

216 Kitale

217 Kericho

218 Furancungo

219 Mocuba

220 Mabote
221 Makamini

222 Grand Comore

223 Tananarive

224 Antsirabe

225 Mauritius

Area 3

301 Taif

302 Cochin

303 Salem

304 Mangalore

305 Bangalore

306 Ahmadnagar

307 Amraoti

308 Nagpur

309 Jubbulpore

310 Sambalpur

311 Cutlack

312 Patna

313 Calcutta

314 Dacca

315 Bhamo

316 Lashio

317 Akyab
318 Yamethin

319 Chiangmai

320 Rangoom

321 Tharrawaddy

322 Sakon Nakhon

323 Bangkok

324 Bontoc

325 Baguio

326 Kuching

327 Hong Kong

328 Mt. Hagen

329 Oahe

330 Hawaii

331 Rurutu

332 Rapa

Area 4

401 Marble Bar

402 Daly Waters

403 Cairns

404 Croydon

405 Cloncurry

406 Rockhampton

\section{APPENDIX 2}

\section{Hail Days}

TABLE 1 No. 5

Jamaica (West of Kingston)

\begin{tabular}{|c|c|c|c|c|c|c|c|c|c|c|c|c|c|c|c|c|}
\hline Station & $\begin{array}{c}\text { Lat. } \\
\mathrm{N}\end{array}$ & $\begin{array}{l}\text { Long. } \\
\text { W }\end{array}$ & $\underset{(\mathrm{m})}{\text { Alt. }}$ & Jan. & Feb. & Mar. & Apr. & $\begin{array}{r}\mathbf{N} \\
\text { May }\end{array}$ & $\begin{array}{l}\text { Jumber } \\
\text { June }\end{array}$ & $\begin{array}{l}\text { r of cas } \\
\text { JuIy }\end{array}$ & $\begin{array}{l}\text { ses } \\
\text { Aug. }\end{array}$ & Sept. & Oct. & Nov. & Dec. & Record \\
\hline Kingston & $17^{\circ} 56^{\prime}$ & $76^{\circ} 47^{\prime}$ & 03 & & & & 1 & 14 & 4 & 5 & 5 & 4 & 1 & 1 & & $\begin{array}{l}10 \text { years } \\
\text { (years } \\
\text { unspecified) }\end{array}$ \\
\hline
\end{tabular}

TABLE 1 No. 6

Mexico

\begin{tabular}{|c|c|c|c|c|c|c|c|c|c|c|c|c|c|c|c|c|}
\hline Station & $\frac{\text { Lat. }}{\mathrm{N}}$ & $\begin{array}{l}\text { Long. } \\
\text { W }\end{array}$ & $\begin{array}{l}\text { A1t. } \\
(\mathrm{m})\end{array}$ & Jan. & Feb. & Mar. & $\begin{array}{l}\text { ong pe } \\
\text { Apr. }\end{array}$ & $\begin{array}{l}\text { eriod } \\
\text { May }\end{array}$ & $\begin{array}{l}\text { means } \\
\text { June }\end{array}$ & $\begin{array}{l}\text { (year } \\
\text { July }\end{array}$ & $\begin{array}{l}\text { s unspe } \\
\text { Aug. }\end{array}$ & $\begin{array}{l}\text { ecified) } \\
\text { Sept. }\end{array}$ & Oct. & Nov. & Dec. & Record \\
\hline \multicolumn{17}{|l|}{ (Chiapas) } \\
\hline $\begin{array}{l}\text { Cd. Las Casas } \\
\text { (Distrito Federal) }\end{array}$ & $16^{\circ} 44^{\prime}$ & $92^{\circ} 38^{\prime}$ & 2128 & $<1$ & $<1$ & 1 & 1 & 1 & 1 & $<1$ & $<1$ & $<1$ & $<1$ & $<1$ & 1 & \\
\hline $\begin{array}{l}\text { Tacubaya } \\
\text { (Durango) }\end{array}$ & $19^{\circ} 24^{\prime}$ & $99^{\circ} 12^{\prime}$ & 2306 & & $<1$ & 1 & 1 & 1 & 1 & 2 & 1 & 1 & $<1$ & $<1$ & & \\
\hline $\begin{array}{l}\text { El Salto } \\
\text { (Guanajuato) }\end{array}$ & $23^{\circ} 47^{\prime}$ & $105^{\circ} 22^{\prime}$ & 2560 & $<1$ & 1 & $<1$ & $<1$ & 1 & 3 & 2 & 2 & $<1$ & $<t$ & $<1$ & $<1$ & \\
\hline $\begin{array}{l}\text { Guanajuato } \\
\text { (Hidalgo) }\end{array}$ & $21^{\circ} 01^{\prime}$ & $101^{\circ} 15^{\prime}$ & 20.37 & $<1$ & $<1$ & $<1$ & $<1$ & 1 & 1 & $<1$ & 1 & $<1$ & $<1$ & $<1$ & $<1$ & \\
\hline Pachuca & $20^{\circ} 08^{\prime}$ & $98^{\circ} 44^{\prime}$ & 2435 & & $<1$ & 1 & 1 & 1 & 1 & $<1$ & 1 & $<1$ & $<1$ & $<1$ & $<1$ & \\
\hline Tula & $20^{\circ} 04^{\prime}$ & $99^{\circ} 21^{\prime}$ & 2030 & & $<1$ & $<1$ & 1 & 1 & $<1$ & 1 & 1 & $<1$ & $<1$ & $<1$ & $<1$ & \\
\hline Apam & $19^{\circ} 41^{\prime}$ & $98^{\circ} 28^{\prime}$ & & $<1$ & $<1$ & $<1$ & 1 & 1 & 1 & 1 & 1 & $<1$ & $<1$ & $<1$ & $<1$ & \\
\hline $\begin{array}{l}\text { Tulancingo } \\
\text { (Mexico) }\end{array}$ & $20^{\circ} 05^{\prime}$ & $98^{\circ} 22^{\prime}$ & 2181 & & $<1$ & $<1$ & 1 & 1 & 1 & $<1$ & $<1$ & $<1$ & $<1$ & $<1$ & $<1$ & \\
\hline Ixtlahuaca & $19^{\circ} 32^{\prime}$ & $99^{\circ} 44^{\prime}$ & & $<1$ & $<1$ & $<1$ & $<1$ & 1 & $<1$ & 1 & 1 & $<1$ & 1 & $<1$ & $<1$ & \\
\hline Toluca & $19^{\circ} 18^{\prime}$ & $99^{\circ} 40^{\prime}$ & 2704 & $<1$ & $<1$ & $<1$ & $<1$ & 1 & $<1$ & 1 & 1 & $<1$ & $<1$ & $<1$ & $<1$ & \\
\hline $\begin{array}{l}\text { Morelia } \\
\qquad \text { (Oaxaca) }\end{array}$ & $19^{\circ} 24^{\prime}$ & $101^{\circ} 11^{\prime}$ & 1923 & $<1$ & $<1$ & & 1 & 1 & 1 & 1 & 1 & $<1$ & $<1$ & $<1$ & $<1$ & \\
\hline $\begin{array}{l}\text { Tlaxiaco } \\
\text { (Puebla) }\end{array}$ & $17^{\circ} 16^{\prime}$ & $97^{\circ} 41^{\prime}$ & 2010 & $<1$ & $<1$ & $<1$ & 1 & 2 & 1 & 1 & 1 & $<1$ & $<1$ & 1 & $<1$ & \\
\hline San M. Texmelucan & $18^{\circ} 29^{\prime}$ & $95^{\circ} 14^{\prime}$ & & & $<1$ & & $<1$ & 1 & 1 & 1 & 1 & $<1$ & $<1$ & $<1$ & $<1$ & \\
\hline Puebla & $19^{\circ} 03^{\prime}$ & $98^{\circ} 12^{\prime}$ & 2150 & $<1$ & $<1$ & $<1$ & $<1$ & 1 & 1 & 1 & 2 & 1 & $<1$ & $<1$ & $<1$ & \\
\hline $\begin{array}{l}\text { Tepeaca } \\
\text { (Tlaxcala) }\end{array}$ & $18^{\circ} 57^{\prime}$ & $97^{\circ} 55^{\prime}$ & & $<1$ & $<1$ & $<1$ & 1 & 2 & 1 & 1 & 1 & 1 & 1 & $<1$ & $<1$ & \\
\hline Huamantla & $19^{\circ} 19^{\prime}$ & $97^{\circ} 55^{\prime}$ & & $<1$ & $<1$ & $<1$ & 1 & 2 & 1 & 1 & 1 & 1 & $<1$ & $<1$ & $<1$ & \\
\hline $\begin{array}{l}\text { Mazapa } \\
\text { (Zacatecas) }\end{array}$ & & & & $<1$ & $<1$ & 1 & 1 & 1 & 1 & 1 & 1 & 1 & 1 & $<1$ & $<1$ & \\
\hline Zacatecas & $22^{\circ} 47^{\prime}$ & $102^{\circ} 35^{\prime}$ & 2612 & $<1$ & $<1$ & $<1$ & $<1$ & $<1$ & 1 & 1 & 1 & $<1$ & $<1$ & $<1$ & $<t$ & \\
\hline
\end{tabular}


TABle 1 No. 7

Costa Rica

\begin{tabular}{|c|c|c|c|c|c|c|c|c|c|c|c|c|c|c|}
\hline Station & Lat. & Long. & $\underset{(\mathrm{m})}{\text { Alt. }}$ & Jan. & Feb. Mar. & $\begin{array}{l}\text { Number of } \\
\text { Apr. May }\end{array}$ & $\begin{array}{l}\text { i cases } \\
\text { June }\end{array}$ & $\begin{array}{l}\text { (Years } \\
\text { July }\end{array}$ & $\begin{array}{l}1960- \\
\text { Aug. }\end{array}$ & $\begin{array}{l}-1964) \\
\text { Sept. }\end{array}$ & Oct. & Nov. & Dec. & Record \\
\hline $\begin{array}{l}\text { San Isidro del } \\
\text { General }\end{array}$ & $09^{\circ} 27^{\prime}$ & $83^{\circ} 45^{\prime}$ & 730 & & & 1 & & & & & & & & \\
\hline Sanatorio Duran & & & & & & & & & & 1 & & & & \\
\hline Villa Mills & $09^{\circ} 31^{\prime}$ & $83^{\circ} 45^{\prime}$ & 1620 & & & & & & & 1 & & & & \\
\hline El Coco & $09^{\circ} 59^{\prime}$ & $84^{\circ} 13^{\prime}$ & 920 & & & 3 & & 1. & 4 & 2 & 1 & & & \\
\hline Maranjo & $10^{\circ} 06^{\prime}$ & $84^{\circ} 22^{\prime}$ & 1060 & & & & & & 1 & & & & & \\
\hline Santa Ana & $09^{\circ} 57^{\prime}$ & $84^{\circ} 10^{\prime}$ & 937 & & & & & & 2 & & & & & \\
\hline San Vito del Jaba & & & & & & & & & & 1. & & & & \\
\hline Pacayas & & & & & & & & & & & & & & \\
\hline Vara Blanca & $10^{\circ} 10^{\prime}$ & $84^{\circ} 08^{\prime}$ & 1700 & & & 2 & & & & & & & & \\
\hline $\begin{array}{l}\text { E1 Guarco } \\
\text { Avance }\end{array}$ & $09^{\circ} 52^{\prime}$ & $83^{\circ} 58^{\prime}$ & 1500 & & & 1 & 1 & 2 & 2 & 2 & & & & \\
\hline
\end{tabular}

TABle 1 No. 8

Honduras

\begin{tabular}{|c|c|c|c|c|c|c|c|c|c|c|c|c|c|c|c|}
\hline Station & $\begin{array}{c}\text { Lat. } \\
\mathrm{N}\end{array}$ & $\underset{W}{\text { Long. }}$ & $\underset{(\mathrm{m})}{\text { Alt. }}$ & Jan. & Feb. & Mar. & Apr. & $\begin{array}{r}\mathrm{N} \\
\text { May }\end{array}$ & $\begin{array}{l}\text { umber } \\
\text { June }\end{array}$ & $\begin{array}{l}\text { of cas } \\
\text { July }\end{array}$ & $\begin{array}{l}\text { ses } \\
\text { Aug. }\end{array}$ & Sept. & Oct. & Nov. Dec. & Record \\
\hline Santa Rosa de Copan & $14^{\circ} 47^{\prime}$ & $88^{\circ} 47^{\prime}$ & 1079 & & & & 3 & 4 & 2 & & & 3 & & & $1957-1963$ \\
\hline Toncontin & $14^{\circ} 04^{\prime}$ & $87^{\circ} 13^{\prime}$ & 990 & & & & 4 & 7 & 11 & 7 & 7 & 5 & & 1 & $1946-1963$ \\
\hline Amapala & $13^{\circ} 1,7^{\prime}$ & $87^{\circ} 39^{\prime}$ & 05 & & & & 1 & 2 & 4 & 3 & 3 & 3 & 3 & & $1954-1960$ \\
\hline
\end{tabular}

TAble 1 No. 10

Argentina

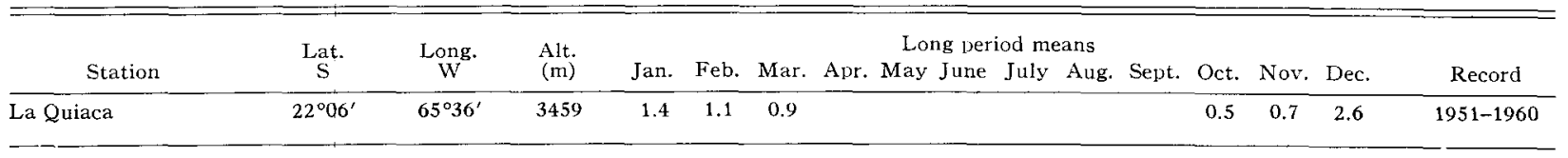

TABLE 1 No. 11

Brazil

\begin{tabular}{|c|c|c|c|c|c|c|c|c|c|c|c|c|c|c|c|c|}
\hline Station & $\begin{array}{c}\mathrm{S} \\
\text { Lat. }\end{array}$ & $\begin{array}{c}\text { W } \\
\text { Long. }\end{array}$ & $\begin{array}{l}\text { (m) } \\
\text { Alt. }\end{array}$ & Jan. & Feb. & Mar. & $\begin{array}{r}\text { Apr. } \\
\mathrm{N}\end{array}$ & $\begin{array}{l}\text { May } \\
\text { mber }\end{array}$ & $\begin{array}{l}\text { June } \\
\text { of case }\end{array}$ & $\begin{array}{c}\text { July } \\
\text { ses (19. }\end{array}$ & $\begin{array}{l}\text { Aug. } \\
43-196\end{array}$ & $\begin{array}{l}\text { Sept. } \\
\text { 60) }\end{array}$ & Oct. & Nov. & Dec. & Record \\
\hline Barretos & $20^{\circ} 33^{\prime}$ & $48^{\circ} 34^{\prime}$ & & & & 1 & & & & & & 3 & 3 & 1 & & \\
\hline Colina & $20^{\circ} 43^{\prime}$ & $48^{\circ} 33^{\prime}$ & & 1 & 1 & 1 & 1 & & 2 & & 1 & & 4 & 4 & 1 & \\
\hline Franca & $20^{\circ} 33^{\prime}$ & $47^{\circ} 26^{\prime}$ & 1036 & 3 & 6 & 3 & 2 & & & & 4 & 4 & 5 & 2 & 5 & \\
\hline Sorocaba & $23^{\circ} 30^{\prime}$ & $47^{\circ} 27^{\prime}$ & & & & 2 & 2 & & & 1 & 1 & & & 3 & & \\
\hline Santa Sofia & $21^{\circ} 26^{\prime}$ & $48^{\circ} 49^{\prime}$ & & 1 & & 2 & 1 & & & & 1 & 1 & 2 & & 4 & \\
\hline Sertaozinho & $21^{\circ} 08^{\prime}$ & $47^{\circ} 59^{\prime}$ & & 2 & 1 & 1 & & 1 & & & 1 & 1 & 1 & 1 & 1 & \\
\hline Riberao Preto & $21^{\circ} 11^{\prime}$ & $47^{\circ} 43^{\prime}$ & 576 & & 2 & 1 & & & & 1 & & 1 & 2 & 3 & 1 & \\
\hline Sao Simao & $21^{\circ} 29^{\prime}$ & $47^{\circ} 33^{\prime}$ & & 3 & & 3 & & & & 1 & 1 & 2 & 3 & 2 & & \\
\hline Campinas & $22^{\circ} 54^{\prime}$ & $47^{\circ} 04^{\prime}$ & 526 & 2 & 1 & 2 & & 2 & 3 & 1 & & 1 & 1 & 2 & 2 & \\
\hline Monte Alegra & $22^{\circ} 42^{\prime}$ & $46^{\circ} 30^{\prime}$ & & 4 & 2 & 1 & & 1 & 1 & 2 & 1 & 1 & & 1 & & \\
\hline Avare & $23^{\circ} 06^{\prime}$ & $48^{\circ} 55^{\prime}$ & 760 & 1 & & 1 & 1 & 2 & & 1 & 3 & 1 & 3 & 3 & 1 & \\
\hline Itapeva & $23^{\circ} 59^{\prime}$ & $48^{\circ} 53^{\prime}$ & 697 & 3 & 1 & & 3 & 2 & 1. & 1 & 3 & 4 & 7 & 1 & & \\
\hline Itapetininga & $23^{\circ} 53^{\prime}$ & $48^{\circ} 03^{\prime}$ & 645 & 1 & 4 & 1 & & & & 1 & 2 & 1 & & & 3 & \\
\hline Tiete & $23^{\circ} 00^{\prime}$ & $47^{\circ} 43^{\prime}$ & & 4 & 1 & & & & & 1 & 2 & 1 & 3 & 1 & 1 & \\
\hline Aqua Branca & $23^{\circ} 32^{\prime}$ & $46^{\circ} 38^{\prime}$ & & 2 & 1 & & 1 & & & 1 & & 1 & 1 & 3 & 1 & \\
\hline Sao Paulo & $23^{\circ} 30^{\prime}$ & $46^{\circ} 37^{\prime}$ & 801 & 6 & 2 & 1 & & 3 & 1 & 1 & 2 & 4 & 3 & 2 & 2 & \\
\hline Tambata & $23^{\circ} 01^{\prime}$ & $45^{\circ} 34^{\prime}$ & 586 & & & 2 & 1 & & & & & & 2 & 1 & 3 & \\
\hline Itu & $23^{\circ} 16^{\prime}$ & $47^{\circ} 17^{\prime}$ & & 2 & 3 & & & 1 & & 3 & 1 & 1 & 3 & & 2 & \\
\hline Paraibuna & $22^{\circ} 01^{\prime}$ & $43^{\circ} 17^{\prime}$ & & 3 & 7 & & 3 & 2 & & 1 & & 3 & 3 & 1 & 3 & \\
\hline Cunha & $23^{\circ} 07^{\prime}$ & $45^{\circ} 08^{\prime}$ & & 1 & 6 & 3 & 1 & 1 & 1 & 1 & & & 7 & 3 & 1 & \\
\hline Horto Forestal & $23^{\circ} 27^{\prime}$ & $46^{\circ} 39^{\prime}$ & & 5 & 4 & 1 & & 1 & & 1 & 2 & 3 & 4 & 3 & 4 & \\
\hline Tramemba & $22^{\circ} 58^{\prime}$ & $45^{\circ} 33^{\prime}$ & & 1 & 2 & 2 & & 3 & 1 & & & & 3 & 3 & 3 & \\
\hline Resende & $22^{\circ} 29^{\prime}$ & $44^{\circ} 38^{\prime}$ & 434 & 4 & 4 & 2 & 1 & & & & & 1 & & 2 & 4 & - \\
\hline Vassouras & $22^{\circ} 24^{\prime}$ & $43^{\circ} 40^{\prime}$ & 428 & 3 & 3 & 1 & 3 & 2 & & & & 1 & 1 & 3 & 1 & \\
\hline Santa Rita & $21^{\circ} 40^{\prime}$ & $47^{\circ} 30^{\prime}$ & & 3 & 2 & & 1 & 2 & 1 & 1 & 2 & 1 & 4 & 1 & 1 & \\
\hline Pirasunnunga & $22^{\circ} 02^{\prime}$ & $47^{\circ} 30^{\prime}$ & 670 & & & 1 & 1 & & & 2 & & 1 & 3 & & 1 & \\
\hline Aracatuba & $21^{\circ} 12^{\prime}$ & $50^{\circ} 26^{\prime}$ & 401 & 3 & 2 & & 2 & & & & & 2 & 3 & & 1 & \\
\hline Catanduva & $21^{\circ} 08^{\prime}$ & $48^{\circ} 58^{\prime}$ & 511 & & 1 & & 1 & 1 & & & 2 & & 2 & & 1 & \\
\hline Mococa & $21^{\circ} 27^{\prime}$ & $47^{\circ} 21^{\prime}$ & 640 & & 5 & & 1 & & & & & 2 & 6 & 5 & & \\
\hline Pindamonhagaba & $22^{\circ} 58^{\prime}$ & $45^{\circ} 29^{\prime}$ & & 3 & 1 & & & 1 & & & & 1 & 2 & & 2 & \\
\hline Guaratiqueta & $22^{\circ} 50^{\prime}$ & $45^{\circ} 11^{\prime}$ & & 3 & 2 & 4 & 2 & 2 & & 1 & & & 3 & 3 & & \\
\hline Piquete & $22^{\circ} 36^{\prime}$ & $45^{\circ} 10^{\prime}$ & 654 & 3 & 1 & 1 & & & & & & 2 & 2 & 1 & & \\
\hline Bandeirante & $22^{\circ} 36^{\prime}$ & $44^{\circ} 28^{\prime}$ & 533 & & 3 & 2 & & & & & & 1 & & 1 & 2 & \\
\hline Baranal & $22^{\circ} 42^{\prime}$ & $44^{\circ} 19^{\prime}$ & & & 4 & 1 & & & & & & 1 & 2 & 1 & 1 & \\
\hline Campos do Jordao & $22^{\circ} 44^{\prime}$ & $45^{\circ} 35^{\prime}$ & 1655 & 13 & 4 & 3 & 1 & 1 & & 3 & 5 & & 6 & 3 & 2 & \\
\hline Presedente Prudenti & $22^{\circ} 07^{\prime}$ & $51^{\circ} 23^{\prime}$ & 455 & & 4 & 1 & & 1 & & & & 2 & 2 & 2 & & \\
\hline Piracicala & $22^{\circ} 43^{\prime}$ & $47^{\circ} 38^{\prime}$ & & 2 & 2 & 2 & & & 1 & & & 2 & 4 & 2 & 2 & \\
\hline
\end{tabular}


Table 1 No. 11 (Continued).

B razil

\begin{tabular}{|c|c|c|c|c|c|c|c|c|c|c|c|c|c|c|c|c|}
\hline Station & $\begin{array}{c}\text { S } \\
\text { Lat. }\end{array}$ & $\begin{array}{c}\text { W } \\
\text { Long. }\end{array}$ & $\begin{array}{l}\text { (m) } \\
\text { Alt. }\end{array}$ & Jan. & lieb. & - Mar. & $\begin{array}{l}\text { Avr. } \\
\text { N }\end{array}$ & $\begin{array}{l}\text { Aay } \\
\text { mbe }\end{array}$ & $\begin{array}{l}\text { June } \\
\text { of ca }\end{array}$ & $\begin{array}{l}\text { July } \\
\text { ses (1 }\end{array}$ & $\begin{array}{l}\text { Aug. } \\
1943-19\end{array}$ & $\begin{array}{l}\text { Sept. } \\
960)\end{array}$ & Oct. & Nov. & Dec. & Record \\
\hline Botucatu & $22^{\circ} 52^{\prime}$ & $48^{\circ} 27^{\prime}$ & & 2 & 1 & 2 & & 1 & & 2 & & 1 & & 1 & 2 & \\
\hline S. Carlos do Pinhel & $22^{\circ} 01^{\prime}$ & $47^{\circ} 53^{\prime}$ & 847 & 2 & & 2 & 1 & 2 & 2 & 1 & 2 & 1 & & 4 & 6 & \\
\hline Limeira & $22^{\circ} 31^{\prime}$ & $47^{\circ} 25^{\prime}$ & & & 3 & & & 1 & & & 1 & & 2 & 1 & & \\
\hline Nova Friburgo & $22^{\circ} 17^{\prime}$ & $42^{\circ} 32^{\prime}$ & 848 & 3 & 2 & & 1 & 1 & & 1 & & & & 1 & 2 & \\
\hline Pinheral & $22^{\circ} 31^{\prime}$ & $44^{\circ} 00^{\prime}$ & & & 1 & 1 & 1 & & & 1 & 1 & & 2 & & 4 & \\
\hline Rio D'ouro & $22^{\circ} 37^{\prime}$ & $43^{\circ} 28^{\prime}$ & 128 & 4 & 1 & 1 & & & & & & 1 & & 1 & & \\
\hline St. Antonio de Padua & $21^{\circ} 32^{\prime}$ & $42^{\circ} 12^{\prime}$ & & 2 & & & & 1 & & & & & & 4 & 2 & \\
\hline Carmo & $21^{\circ} 55^{\prime}$ & $42^{\circ} 37^{\prime}$ & 343 & & 1 & & 2 & 1 & & 1 & & 2 & & 1 & & \\
\hline Paracatu & $17^{\circ} 13^{\prime}$ & $46^{\circ} 52^{\prime}$ & 607 & 3 & 2 & & & & & & & 1 & 1 & 2 & 1 & \\
\hline Iramarandiba & $17^{\circ} 51^{\prime}$ & $42^{\circ} 51^{\prime}$ & 974 & & & 1 & 3 & & & & & 1 & 3 & 2 & 1 & \\
\hline Pitangui & $19^{\circ} 41^{\prime}$ & $44^{\circ} 46^{\prime}$ & 640 & 3 & 1 & 1 & & & & 1 & & 1 & 2 & & & \\
\hline Diamantina & $18^{\circ} 15^{\prime}$ & $43^{\circ} 15^{\prime}$ & 1260 & 4 & 3 & 2 & 3 & 2 & & & 1 & 2 & 4 & 5 & 1 & \\
\hline S. J. Evangelista & $18^{\circ} 25^{\prime}$ & $42^{\circ} 47^{\prime}$ & & 2 & & 2 & & & & 1 & & 1 & 1 & 1 & 1 & \\
\hline Uberaba & $19^{\circ} 46^{\prime}$ & $47^{\circ} 56^{\prime}$ & 748 & 3 & 1 & & & 1 & & & & & 1 & 2 & 2 & \\
\hline Bambui & $20^{\circ} 00^{\prime}$ & $45^{\circ} 59^{\prime}$ & 659 & 1 & 2 & & & & & & & & 7 & 4 & 2 & \\
\hline Belo Horizonta & $19^{\circ} 56^{\prime}$ & $43^{\circ} 56^{\prime}$ & 785 & & & & & & 1 & & 2 & 2 & 4 & 1 & & \\
\hline Lagoa Santa & $19^{\circ} 37^{\prime}$ & $43^{\circ} 53^{\prime}$ & & 3 & 2 & 1 & & 1 & & & 2 & & 2 & 2 & & \\
\hline Itabira & $19^{\circ} 37^{\prime}$ & $43^{\circ} 13^{\prime}$ & & 3 & 1 & & 1 & 1 & 1 & & 1 & 2 & 5 & 2 & & \\
\hline S. Sebastiao & $20^{\circ} 54^{\prime}$ & $46^{\circ} 59^{\prime}$ & & 2 & & 1 & 1 & & 1 & 1 & 1 & 3 & 11 & 6 & 9 & \\
\hline Oliveria & $20^{\circ} 41^{\prime}$ & $44^{\circ} 49^{\prime}$ & 962 & & & 1 & & & & & 2 & 2 & 1 & 1 & 1 & \\
\hline Pocoa de Caldes & $21^{\circ} 47^{\prime}$ & $46^{\circ} 33^{\prime}$ & 1186 & 3 & 1 & 1 & & & 1 & & 1 & 1 & 5 & 1 & 3 & \\
\hline Muxambino & $21^{\circ} 22^{\prime}$ & $46^{\circ} 32^{\prime}$ & 1052 & 4 & 1 & 5 & 2 & 1 & & 3 & 1 & 1 & 13 & 5 & 2 & \\
\hline Tres Coracoas & $21^{\circ} 42^{\prime}$ & $45^{\circ} 15^{\prime}$ & & 1 & 3 & & & & & & 1 & 2 & 2 & 2 & 1 & \\
\hline Caxambu & $21^{\circ} 59^{\prime}$ & $44^{\circ} 56^{\prime}$ & 890 & & & & 1 & 1 & 1 & & & 3 & 2 & 2 & 4 & \\
\hline Barbacaná & $21^{\circ} 15^{\prime}$ & $43^{\circ} 46^{\prime}$ & & 3 & 1 & & & & 1 & & 1 & 1 & 1 & 3 & & \\
\hline Santos Dumont & $21^{\circ} 27^{\prime}$ & $43^{\circ} 33^{\prime}$ & 850 & 2 & 2 & & & & & & & & 1 & 4 & & \\
\hline Uba & $21^{\circ} 07^{\prime}$ & $42^{\circ} 57^{\prime}$ & & & & 1 & 3 & & & & & 1 & 1 & 1 & 2 & \\
\hline Lespoldina & $21^{\circ} 32^{\prime}$ & $42^{\circ} 38^{\prime}$ & 268 & 2 & & 1 & & & & & & & 3 & 3 & & \\
\hline Itajuba & $22^{\circ} 25^{\prime}$ & $45^{\circ} 27^{\prime}$ & & & 2 & 2 & & & 2 & 1 & 2 & 4 & 4 & 4 & 6 & \\
\hline Passa Quatro & $22^{\circ} 23^{\prime}$ & $44^{\circ} 58^{\prime}$ & 916 & 2 & 1 & 3 & & & & 1 & & 5 & 5 & 1 & 2 & \\
\hline Utiariti & $13^{\circ} 02^{\prime}$ & $58^{\circ} 14^{\prime}$ & 385 & & 1 & & & 1 & & 2 & 2 & 2 & 1 & & 1 & \\
\hline Campo Grande & $20^{\circ} 27^{\prime}$ & $54^{\circ} 37^{\prime}$ & 563 & 1 & 1 & & & & & 2 & & 2 & $\bar{T}$ & & & \\
\hline Ponta Pora & $22^{\circ} 32^{\prime}$ & $55^{\circ} 37^{\prime}$ & 660 & & & & 1 & 2 & & & & 4 & & & 2 & \\
\hline Formosa & $15^{\circ} 32^{\prime}$ & $47^{\circ} 18^{\prime}$ & 906 & 1 & 1 & & & & & & & 1 & 4 & 4 & 1 & \\
\hline S. Ant. de Jesus & $12^{\circ} 58^{\prime}$ & $39^{\circ} 16^{\prime}$ & 207 & & 1 & 2 & 7 & 1 & & & & & 1 & 5 & 1 & \\
\hline Petrolandia & $09^{\circ} 04^{\prime}$ & $38^{\circ} 19^{\prime}$ & & & & 1 & 1 & & & 4 & 3 & 1 & 1 & 1 & 1 & \\
\hline
\end{tabular}

TABLE 1 No. 12

Paraguay

\begin{tabular}{|c|c|c|c|c|c|c|c|c|c|c|c|c|c|c|c|c|}
\hline Station & Lat. & $\begin{array}{l}\text { Long. } \\
\text { W }\end{array}$ & Alt. & $\therefore$ Jan. & Feb. & Mar. & $\begin{array}{l}\text { Lon } \\
\text { Apr. }\end{array}$ & $\begin{array}{l}\text { Meri } \\
\text { May }\end{array}$ & $\begin{array}{l}\text { iod me } \\
\text { June }\end{array}$ & $\begin{array}{l}\text { Juns } \\
\text { July }\end{array}$ & $\begin{array}{l}1941-19 \\
\text { Aug. }\end{array}$ & $\begin{array}{l}960) \\
\text { Sept. }\end{array}$ & Oct. & Nov. & Dec. & Record \\
\hline Pedro Juan Caballero & $22^{\circ} 35^{\prime}$ & $55^{\circ} 39^{\prime}$ & 614 & & 0.2 & 0.2 & & & & & 0.4 & 0.8 & 0.6 & & & \\
\hline Horqueta & $23^{\circ} 50^{\prime}$ & $57^{\circ} 08^{\prime}$ & & 0.07 & 0.07 & & & 0.2 & 0.1 & 0.5 & 0.4 & 0.5 & 0.3 & 0.07 & & \\
\hline San Lorenzo & $25^{\circ} 22^{\prime}$ & $57^{\circ} 34^{\prime}$ & 131 & & & & 0.14 & & & 0.14 & 0.14 & 0.57 & 0.43 & 0.57 & 0.29 & \\
\hline Asuncion & $25^{\circ} 16^{\prime}$ & $57^{\circ} 38^{\prime}$ & 65 & & 0.05 & 0.05 & & 0.1 & 0.05 & & 0.3 & 0.4 & 0.4 & 0.1 & 0.05 & \\
\hline Pto. Pte Franco & $25^{\circ} 32^{\prime}$ & $54^{\circ} 35^{\prime}$ & 125 & 0.05 & 0.05 & 0.05 & & & 0.1 & 0.1 & 0.05 & 0.7 & 0.2 & 0.05 & 0.1 & \\
\hline Villarrica & $25^{\circ} 45^{\prime}$ & $56^{\circ} 26^{\prime}$ & 157 & & & & & & & & 0.2 & 0.5 & 0.2 & & 0.3 & \\
\hline Pilar & $26^{\circ} 51^{\prime}$ & $58^{\circ} 19^{\prime}$ & 59 & 0.10 & 0.05 & & 0.05 & & & 0.1 & 0.1 & 0.3 & 0.4 & 0.2 & & \\
\hline Encarnacion & $27^{\circ} 20^{\prime}$ & $55^{\circ} 50^{\prime}$ & 104 & 0.05 & 0.05 & & 0.1 & 0.1 & & & 0.3 & 0.2 & 0.2 & 0.1 & 0.05 & \\
\hline
\end{tabular}

TABle 1 No. 13

Ecuador

\begin{tabular}{|c|c|c|c|c|c|c|c|c|c|c|c|c|c|c|c|c|}
\hline Station & Lat. & $\begin{array}{l}\text { Long. } \\
\text {. }\end{array}$ & $\begin{array}{l}\text { Alt. } \\
\text { (m) }\end{array}$ & Jan. & Feb. & Mar. & Apr. & $\begin{array}{r}\mathrm{N} \\
\text { May }\end{array}$ & $\begin{array}{l}\text { Jumber } \\
\text { June }\end{array}$ & $\begin{array}{l}\text { of cas } \\
\text { July }\end{array}$ & $\begin{array}{l}\text { ses } \\
\text { Aug. }\end{array}$ & Sept. & Oct. & Nov. & Dec. & Record \\
\hline Izobamba & $00^{\circ} 2.2^{\prime}$ & $78^{\circ} 33^{\prime}$ & 3058 & 5 & 4 & 1 & 7 & 5 & 3 & 4 & 1 & 1 & 3 & & & $1962-1964$ \\
\hline Quito & $00^{\circ} 08^{\prime}$ & $78^{\circ} 29^{\prime}$ & 2812 & & 2 & 1 & & 3 & & 2 & 1 & 3 & 2 & 2 & 2 & $1963-1964$ \\
\hline San Pablo del Lago & $00^{\circ} 10^{\prime} \mathrm{N}$ & $78^{\circ} 14^{\prime}$ & 2680 & & & & & & 1 & & & & & 1 & & $1962-1964$ \\
\hline Cotapaxi & $00^{\circ} 33^{\prime}$ & $78^{\circ} 30^{\prime}$ & 3560 & & & & 1 & 1 & 1 & & & & 2 & 1 & & $1962-1964$ \\
\hline Canar & $02^{\circ} 45^{\prime}$ & $78^{\circ} 51^{\prime}$ & 3104 & & & & & & & & & & 3 & & & $1962-1964$ \\
\hline
\end{tabular}

TABle 1 No. 14

Peru

\begin{tabular}{|c|c|c|c|c|c|c|c|c|c|c|c|c|c|c|c|c|}
\hline Station & Lat. & $\begin{array}{l}\text { Long. } \\
\text { W }\end{array}$ & $\begin{array}{l}\text { Alt. } \\
(\mathrm{m})\end{array}$ & Jan. & Feb. & Mar. & $\begin{array}{l}\mathrm{Nu} \\
\text { Apr. }\end{array}$ & $\begin{array}{l}\text { Imber } \\
\text { May }\end{array}$ & $\begin{array}{l}\text { of cas } \\
\text { June }\end{array}$ & $\begin{array}{l}\text { ses (19 } \\
\text { July }\end{array}$ & $\begin{array}{c}\text { 59-196 } \\
\text { Aug. }\end{array}$ & $\begin{array}{l}\text { 63) } \\
\text { Sept. }\end{array}$ & Oct. & Nov. & Dec. & Record \\
\hline Pachachaca & $11^{\circ} 40^{\prime}$ & $75^{\circ} 55^{\prime}$ & 3971 & 8 & 7 & 3 & 3 & 2 & 1 & & 3 & 7 & 2 & 2 & 2 & \\
\hline
\end{tabular}


TABLE 2 No. 8

Ghana

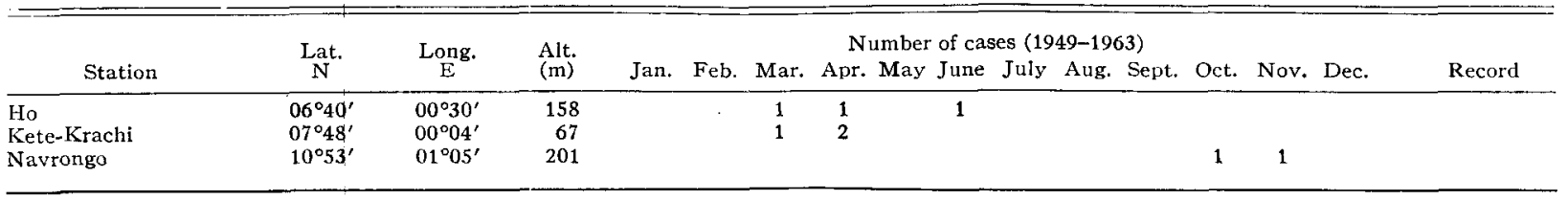

TABLE 2 No. 11

Nigeria

\begin{tabular}{|c|c|c|c|c|c|c|c|c|c|c|c|c|c|c|c|c|}
\hline Station & $\begin{array}{l}\text { Lat: } \\
\mathrm{N}\end{array}$ & $\underset{\mathrm{E}}{\text { Long. }}$ & Alt. & Jan. & Feb. & Mar. & $\begin{array}{r}\mathrm{N} \\
\text { Apr. }\end{array}$ & $\begin{array}{l}\text { umber } \\
\text { May }\end{array}$ & $\begin{array}{l}\text { r of ca } \\
\text { June }\end{array}$ & $\begin{array}{c}\text { ses (19 } \\
\text { July }\end{array}$ & $\begin{array}{r}54-19 \\
\text { Aug. }\end{array}$ & $\begin{array}{l}\text { 63) } \\
\text { Sept. }\end{array}$ & Oct. & Nov. & Dec. & Record \\
\hline Bamenda & $05^{\circ} 58^{\prime}$ & $10^{\circ} 12^{\prime}$ & & 1 & 2 & 5 & 4 & & 1 & & 4 & 2 & & 1 & 1 & \\
\hline Jos & $09^{\circ} 52^{\prime}$ & $08^{\circ} 54^{\prime}$ & 1295 & & & 4 & 4 & 11 & 7 & 2 & 1 & 3 & 1 & & & \\
\hline Ibadan & $07^{\circ} 26^{\prime}$ & $03^{\circ} 54^{\prime}$ & 234 & & & 1 & 2 & & & & & & & & & \\
\hline $\begin{array}{l}\text { Minna } \\
\text { Bauchi }\end{array}$ & $\begin{array}{l}09^{\circ} 37^{\prime} \\
10^{\circ} 17^{\prime}\end{array}$ & $\begin{array}{l}06^{\circ} 32^{\prime} \\
09^{\circ} 49^{\prime}\end{array}$ & $\begin{array}{l}262 \\
591\end{array}$ & & & & & 1 & $\begin{array}{l}1 \\
3\end{array}$ & 1 & & 1 & & & & \\
\hline Nguru & $12^{\circ} 53^{\prime}$ & $10^{\circ} 28^{\prime}$ & 343 & & & & & 1 & 1 & 1 & 1 & 1 & 1 & & & \\
\hline Kano & $12^{\circ} 03^{\prime}$ & $08^{\circ} 32^{\prime}$ & 476 & & & & & 1 & 1 & 1 & & 1 & & & & \\
\hline
\end{tabular}

Table 2 No. 12

Cameroun

\begin{tabular}{|c|c|c|c|c|c|c|c|c|c|c|c|c|c|c|c|c|}
\hline Station & $\underset{\mathrm{N}}{\mathrm{L} a t .}$ & $\underset{E}{\text { Long. }}$ & $\begin{array}{l}\text { Alt. } \\
\text { (m) }\end{array}$ & Jan. & Feb. & Mar. & $\begin{array}{r}\text { N } \\
\text { Apr. }\end{array}$ & $\begin{array}{l}\text { Mbe } \\
\text { May }\end{array}$ & $\begin{array}{l}\text { of ca } \\
\text { June }\end{array}$ & $\begin{array}{l}\text { ses (1S } \\
\text { July }\end{array}$ & $\begin{array}{r}951-19 \\
\text { Aug. }\end{array}$ & $\begin{array}{l}\text { 60) } \\
\text { Sept. }\end{array}$ & Oct. & Nov. & Dec. & Record \\
\hline Yaounde & $03^{\circ} 52^{\prime}$ & $11^{\circ} 32^{\prime}$ & 753 & & 4 & 2 & 1 & & & & & & & & & \\
\hline N. Eboko & $04^{\circ} 39^{\prime}$ & $12^{\circ} 24^{\prime}$ & 622 & & 2 & & 1 & & & & & & & 3 & 1 & \\
\hline Ebolowa & $02^{\circ} 51^{\prime}$ & $11^{\circ} 11^{\prime}$ & 602 & 1 & 1 & 4 & & & & & & & & 1 & & \\
\hline Sangme & $02^{\circ} 56^{\prime}$ & $11^{\circ} 57^{\prime}$ & 712 & & & 1 & 2 & & & & & & & 1 & & \\
\hline Bafia & $04^{\circ} 44^{\prime}$ & $11^{\circ} 15^{\prime}$ & $499 *$ & & 1 & 1 & & & & & & & & & & \\
\hline Yoko & $05^{\circ} 33^{\prime}$ & $12^{\circ} 22^{\prime}$ & 1027 & & 3 & 1 & 3 & & & & & & 1 & 1 & 1 & \\
\hline Batouri & $04^{\circ} 25^{\prime}$ & $14^{\circ} 24^{\prime}$ & 650 & & & 2 & I & & & & 1 & 1 & & 2 & & \\
\hline Garoua & $09^{\circ} 20^{\prime}$ & $13^{\circ} 23^{\prime}$ & 248 & & & & & & & & 1 & & 1 & & & \\
\hline Banyo & $06^{\circ} 47^{\prime}$ & $11^{\circ} 49^{\prime}$ & $1110^{*}$ & & 1 & 3 & 4 & 1 & 1 & 3 & & & 2 & & 1 & \\
\hline Meiganga & $06^{\circ} 32^{\prime}$ & $14^{\circ} 22^{\prime}$ & 1027 & & 3 & 4 & 5 & 1 & 1 & 1 & 1 & 3 & 2 & 2 & & \\
\hline Tibati & $06^{\circ} 29^{\prime}$ & $12^{\circ} 36^{\prime}$ & 873 & & 2 & 2 & 1 & 1 & 1 & & & 2 & 2 & 2 & & \\
\hline Koundja & $05^{\circ} 37^{\prime}$ & $10^{\circ} 45^{\prime}$ & 1208 & 1 & 2 & 3 & 4 & & 2 & & 2 & 2 & & & & \\
\hline
\end{tabular}

* Approximately.

TABle 2 No. 14

Angola

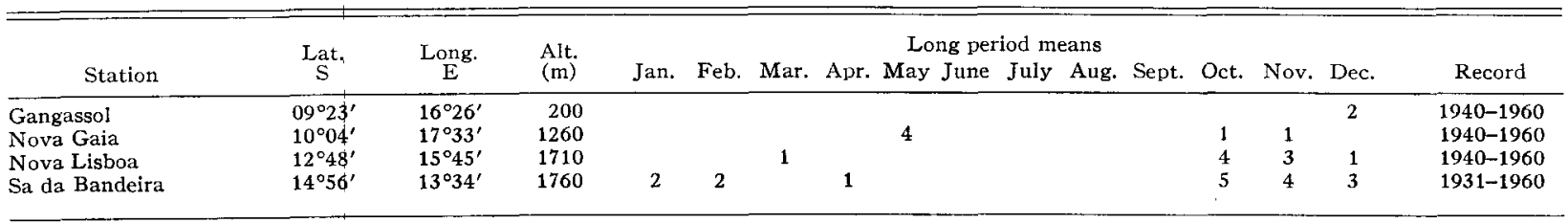

TABle 2 No. 15

Tchad

\begin{tabular}{|c|c|c|c|c|c|c|c|c|c|c|c|c|c|c|c|}
\hline Station & $\begin{array}{c}\text { Lat. } \\
\mathrm{N}\end{array}$ & $\begin{array}{l}\text { Long. } \\
\text { E }\end{array}$ & $\begin{array}{l}\text { Alt. } \\
\text { (m) }\end{array}$ & Jan. & Feb. & Mar. & Apr. & $\begin{array}{r}\mathrm{N} \\
\text { May }\end{array}$ & $\begin{array}{l}\text { umber } \\
\text { June }\end{array}$ & $\begin{array}{l}\text { r of cas } \\
\text { July }\end{array}$ & ses & Sept. & Oct. & Nov. Dec. & Record \\
\hline Fort Archambault & $09^{\circ} 08^{\prime}$ & $18^{\circ} 23^{\prime}$ & 364 & & & & & & 1 & 1 & & & 1 & & $1949-1962$ \\
\hline Fort Lamy & $12^{\circ} 08^{\prime}$ & $15^{\circ} 02^{\prime}$ & 294 & & & & & 1 & 3 & 1 & & 1 & & & $1950-1960$ \\
\hline Bokoro & $12^{\circ} 23^{\prime}$ & $17^{\circ} 03^{\prime}$ & 300 & & & & & 1 & & & 1 & & & & $1950-1960$ \\
\hline Abeche & $13^{\circ} 51^{\prime}$ & $20^{\circ} 51^{\prime}$ & 545 & & & & & 2 & & 2 & & 1 & 1 & . & $1951-1956$ \\
\hline Mao & $14^{\circ} 07^{\prime}$ & $15^{\circ} 19^{\prime}$ & 355 & & & & & $\checkmark$ & 1 & & & 1 & & & $1955-1960$ \\
\hline Pala & $09^{\circ} 22^{\prime}$ & $14^{\circ} 55^{\prime}$ & 454 & & & & & 2 & & & & & 1 & & $1957-1959$ \\
\hline Moundou & $08^{\circ} 37^{\prime}$ & $16^{\circ} 04^{\prime}$ & 420 & & & & 2 & 1 & & . & 1 & & & & 1951-1959 \\
\hline
\end{tabular}

TABLe 2 No. 20

Ethiopia

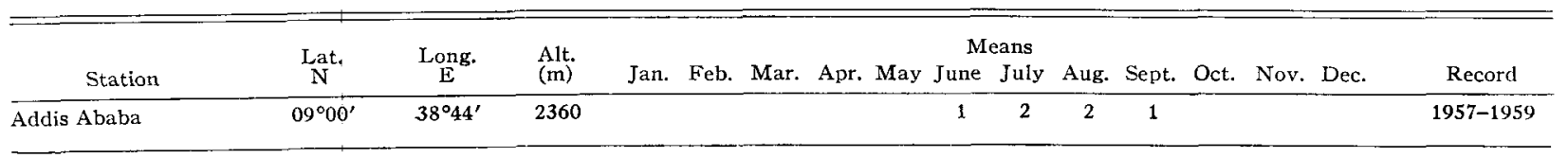


TABLE 2 No. 23

Western Kenya

\begin{tabular}{|c|c|c|c|c|c|c|c|c|c|c|c|c|c|c|c|c|}
\hline Station & Lat. & $\underset{E}{\text { Long. }}$ & $\begin{array}{l}\text { AIt. } \\
\text { (m) }\end{array}$ & Jan. & Feb. & Mar. & Apr. & $\begin{array}{r}N \\
\text { May }\end{array}$ & $\begin{array}{l}\text { umber } \\
\text { June }\end{array}$ & $\begin{array}{l}\text { of cas } \\
\text { July }\end{array}$ & $\begin{array}{l}\text { ses } \\
\text { Aug. }\end{array}$ & Sept. & Oct. & Nov. & Dec. & Record \\
\hline Western Kenya & & & & 5 & 6 & 13 & 9 & 9 & 13 & 10 & 15 & 15 & 10 & 5 & 4 & $1960-1964$ \\
\hline Kericho & $00^{\circ} 22^{\prime}$ & $35^{\circ} 17^{\prime}$ & 2042 & 2 & 3 & 6 & 3 & 4 & 6 & 6 & 5 & 7 & 7 & 2 & 3 & $1960-1964$ \\
\hline
\end{tabular}

TABLE 2 No. 26

Mozambique

\begin{tabular}{|c|c|c|c|c|c|c|c|c|c|c|c|c|c|c|c|c|c|}
\hline Station & & $\underset{\mathrm{S}}{\text { Lat. }}$ & $\underset{\mathrm{E}}{\text { Long. }}$ & $\begin{array}{l}\text { Alt. } \\
\text { (m) }\end{array}$ & Jan. & Feb. & Mar. & Apr. & $\begin{array}{r}\mathrm{N} \\
\text { May }\end{array}$ & $\begin{array}{l}\text { umber } \\
\text { June }\end{array}$ & $\begin{array}{l}r \text { of cas } \\
\text { July }\end{array}$ & $\begin{array}{l}\text { ses } \\
\text { Aug. }\end{array}$ & Sept. & Oct. & Nov. & Dec. & Record \\
\hline Funahouro & & $\overline{23^{\circ} 05^{\prime}}$ & $34^{\circ} 23^{\prime}$ & 116 & & & & 1 & & & & & & & & 5 & $1958-1960$ \\
\hline Mabote & & $22^{\circ} 03^{\prime}$ & $34^{\circ} 07^{\prime}$ & 143 & & & & & & 1 & & 1 & & 2 & 3 & & $1957-1963$ \\
\hline lispungabera & & $20^{\circ} 28^{\prime}$ & $32^{\circ} 46^{\prime}$ & 824 & & & & 1 & & & & & 1 & 1 & 1 & 3 & $1952-1960$ \\
\hline Vila Pery & & $19^{\circ} 07^{\prime}$ & $33^{\circ} 28^{\prime}$ & 731 & 1 & 1 & 1 & & 1 & & & & 1 & 1 & 2 & 2 & $1932-1961$ \\
\hline Inhaminga & & $18^{\circ} 24^{\prime}$ & $35^{\circ} 00^{\prime}$ & 316 & & & & & 1 & 1. & & & & 1 & 2 & 1 & 1940-1962 \\
\hline Mocuba & & $16^{\circ} 50^{\prime}$ & $36^{\circ} 59^{\prime}$ & 134 & 1 & & 1 & & & & 1 & & & 1 & 1 & & $1951-1960$ \\
\hline Tacuane & & $16^{\circ} 21^{\prime}$ & $36^{\circ} 22^{\prime}$ & 400 & & & & & & & 1 & & & & 4 & 1 & 1961 \\
\hline Milange & & $16^{\circ} 06^{\prime}$ & $35^{\circ} 47^{\prime}$ & 745 & & & & & & & & & & 1 & 3 & & 1960 \\
\hline Errego & & $16^{\circ} 02^{\prime}$ & $37^{\circ} 11^{\prime}$ & 533 & 2 & & & & & & & & & & 5 & 2 & $1950-1963$ \\
\hline Fingoe & & $15^{\circ} 10^{\prime}$ & $31^{\circ} 53^{\prime}$ & 857 & 2 & 2 & & & & 1 & 1 & & & & 1 & 1 & $1957-1961$ \\
\hline Lioma & & $15^{\circ} 09^{\prime}$ & $36^{\circ} 46^{\prime}$ & 736 & 1 & & & & & & & & 1 & & 2 & 1 & $1958-1960$ \\
\hline Furancungo & & $14^{\circ} 54^{\prime}$ & $33^{\circ} 36^{\prime}$ & 1259 & & & & & & & & & & 3 & 2 & 1 & $1956-1959$ \\
\hline Nungo & & $13^{\circ} 25^{\prime}$ & $37^{\circ} 46^{\prime}$ & 610 & & & & 1 & & & & & & 2 & 7 & 4 & $1960-1961$ \\
\hline Namara & & $13^{\circ} 21^{\prime}$ & $38^{\circ} 34^{\prime}$ & 579 & & 5 & & & 1 & & & & & & & & $1957-1958$ \\
\hline Vila Calural & & $13^{\circ} 18^{\prime}$ & $35^{\circ} 14^{\prime}$ & 1356 & & & & & & & & & & 4 & 3 & 1 & $1936-1962$ \\
\hline Ancuabe & & $12^{\circ} 58^{\circ}$ & $39^{\circ} 51^{\prime}$ & 349 & 3 & 2 & & & & & & & & & & & $1960-1963$ \\
\hline Maniamba & & $12^{\circ} 46^{\prime}$ & $34^{\circ} 59^{\prime}$ & 1093 & 2 & & & & & & & 1 & & 2 & 2 & 3 & 1934-1962 \\
\hline Nairoto & & $12^{\circ} 24^{\prime}$ & $39^{\circ} 06^{\prime}$ & 311 & & & 5 & & & & & & & & & & 1960 \\
\hline Mueda & & $11^{\circ} 40^{\prime}$ & $39^{\circ} 33^{\prime}$ & 847 & 1 & & 1 & & & & & & & & 4 & 5 & $1957-1961$ \\
\hline Nova Sofola & & $20^{\circ} 09^{\prime}$ & $34^{\circ} 44^{\prime}$ & 10 & & 1 & & 3 & & & & & & & 1 & & $1932-1962$ \\
\hline
\end{tabular}

TABLE 2 No. 27

Rhodesia

\begin{tabular}{|c|c|c|c|c|c|c|c|c|c|c|c|c|c|c|c|c|}
\hline Station & Lat. & $\underset{E}{\text { Long. }}$ & $\begin{array}{l}\text { Alt. } \\
(\mathrm{m})\end{array}$ & Jan. & Feb. & Mar. & $\begin{array}{r}\mathbf{N} \\
\mathrm{M} \circ \\
\mathrm{Apr} .\end{array}$ & $\begin{array}{l}\text { Numb } \\
\text { onthly } \\
\text { May }\end{array}$ & $\begin{array}{l}\text { er of c } \\
\text { avera } \\
\text { June }\end{array}$ & $\begin{array}{l}\text { ases (f } \\
\text { ges (se } \\
\text { July }\end{array}$ & $\begin{array}{l}\text { irst lin } \\
\text { econd } 1 \\
\text { Aug. }\end{array}$ & $\begin{array}{l}\text { lie) } \\
\text { Sept. }\end{array}$ & Oct. & Nov. & Dec. & Record \\
\hline Whole country & $\begin{array}{l}17^{\circ}-21^{\circ} \\
\text { (approx) }\end{array}$ & $\begin{array}{l}27^{\circ}-33^{\circ} \\
\text { (approx) }\end{array}$ & & 100 & 52 & 37 & 59 & 40 & 67 & 1 & 76 & 131 & 251 & 472 & 306 & $1957-1964$ \\
\hline Whole country & & & & 14.3 & 7.4 & 5.3 & 8.4 & 5.7 & 9.6 & & 10.9 & 18.7 & 36.0 & 67.4 & 43.7 & $1957-1964$ \\
\hline
\end{tabular}

Table 2 No. 29

Madagascar

\begin{tabular}{|c|c|c|c|c|c|c|c|c|c|c|c|c|c|c|c|c|c|c|}
\hline Station & & $\begin{array}{c}\text { Lat. } \\
\text { S }\end{array}$ & $\underset{\mathrm{E}}{\text { Long. }}$ & $\begin{array}{l}\text { Alt } \\
\text { (m) }\end{array}$ & & Jan. & Feb. & Mar. & Apr. & $\begin{array}{r}\text { Lo } \\
\text { May }\end{array}$ & $\begin{array}{c}\text { ong pe } \\
\text { June }\end{array}$ & $\begin{array}{l}\text { eriod m } \\
\text { July }\end{array}$ & $\begin{array}{l}\text { eans } \\
\text { Aug. }\end{array}$ & Sept. & Oct. & Nov. & Dec. & Record \\
\hline Whole island & & $\begin{array}{l}13^{\circ}-26^{\circ} \\
\text { (approx) }\end{array}$ & $\begin{array}{l}43^{\circ}-51^{\circ} \\
(\text { approx })\end{array}$ & & & 9.4 & 5.3 & 6.6 & 9.0 & 4.2 & 1.7 & 2.0 & 2.0 & 3.3 & 15.9 & 22.6 & 18.0 & $\begin{array}{l}10 \text { years } \\
\text { (years } \\
\text { unspecified }\end{array}$ \\
\hline
\end{tabular}

TABLE 3 No. 2(a)

India

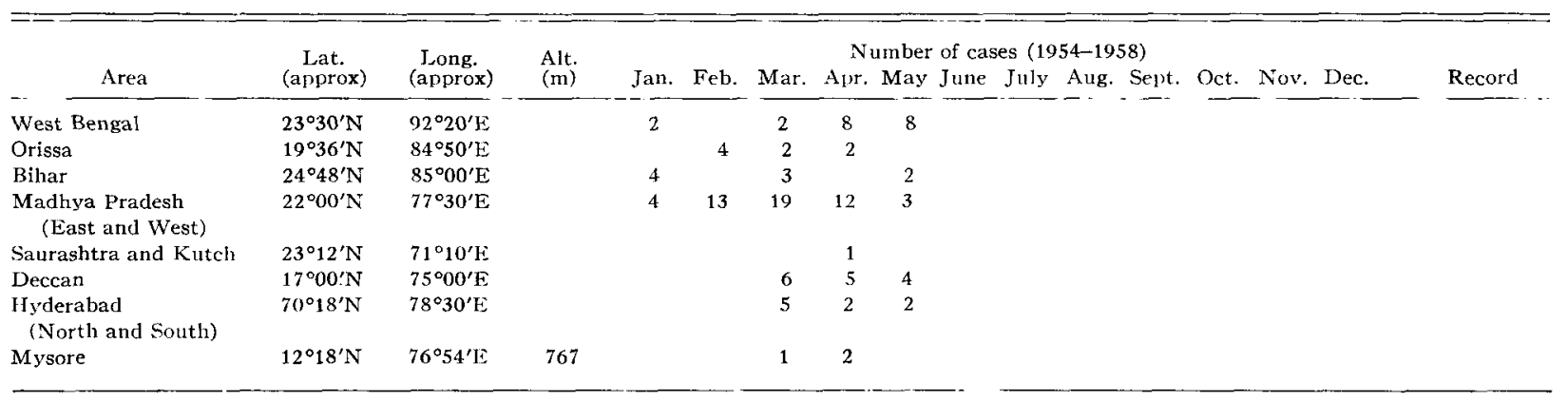


TABLE 3 No. 2(b)

East Pakistan

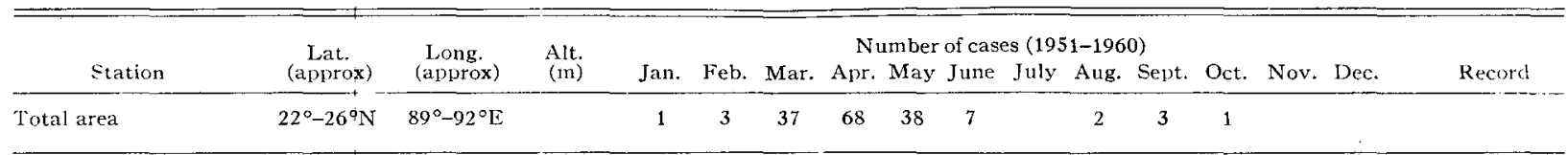

TABLE 3 No. 3

Burma

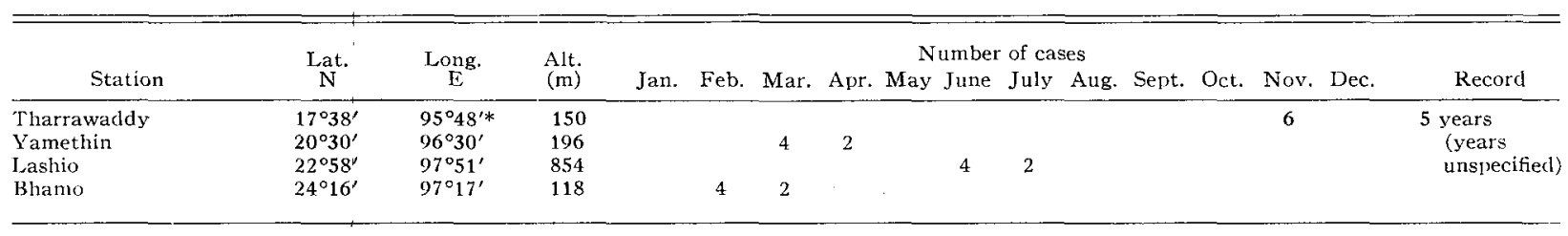

* Approximately.

TABLE 3 No. 5

Thailand

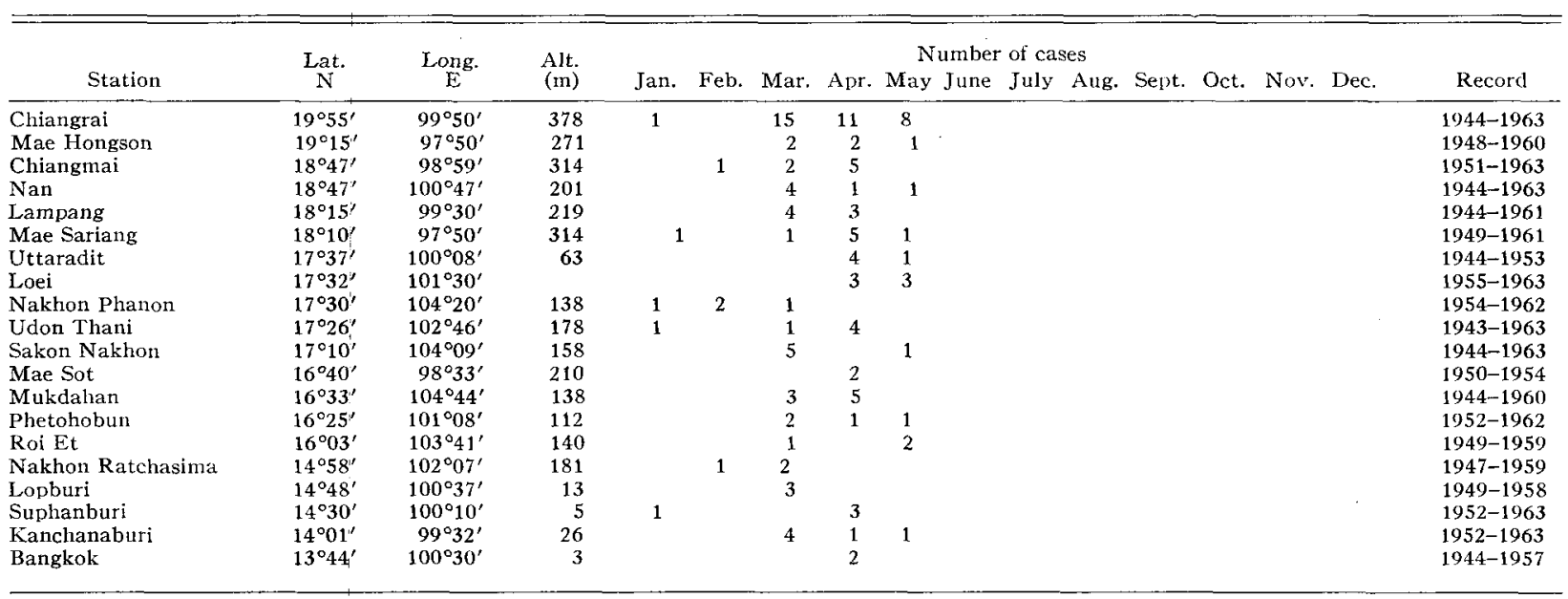

TABLE 3 No. 10

New Guinea

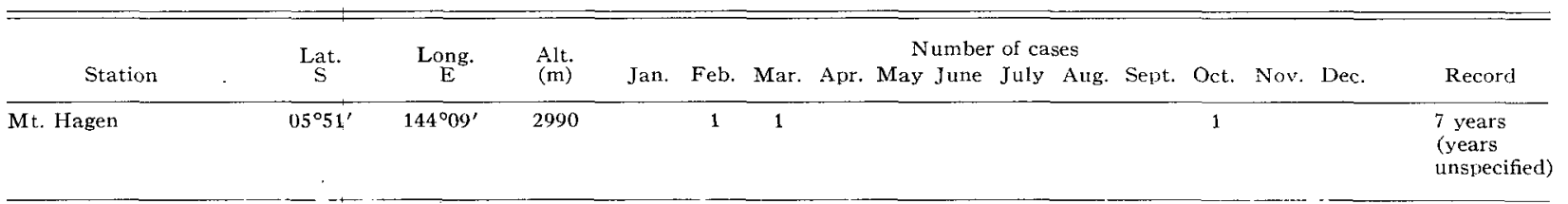

\section{REFERENCES}

Alexander, W. H., 1903: Hailstorms in Puerto Rico. Mon. Wea. Rev., 31, 233-234.

Bougnol, M., 1937: On the occurrence of hailstorms in French West Africa from 1921-1934. Geogr. Rev., 27, 151-152.

Bultot, F., 1959: Ettude statistique des chutes de grele au Congo Belge et au Ruanda-Urundi. Bureau Climtologique Communication No. 17, Bruxelles, 12-36.

Crossley, A. F., 1961 : Hail in relation to the risk of encounters in flight. Meteor. Mag., 90, 106.

Frisby, E. M., 1964: Hailstorms from tropics to midlatitudes. Trans. A. R. O. Tropial Meteorology Research Conference, Fort Monmouth, N. J., 42-51.

1965: The hailstorms of low latitudes. Trans. A. R. O. Tropical Meteorology Research Conference, Fort Monmouth, N. J., 107-120.

Garbell, M. A., 1947: Trppical and Equatorial Meteorology. New York, Pitnam Publishing Co., 240 pp.
Hopkins, B., 1962 : Hail in South-western Nigeria. Weather, 17, 217 Humphreys, W. J., 1940: Physies of the Air. Third edition, New York, McGraw Hill Book Co., $676 \mathrm{pp}$.

Lemons, H., 1942: Hail in high and low latitudes. Bull. Amer. Meleor. Soc., 2, 61-72.

Ramdas, L. A., V. Satakopan and S. Gopal Rao, 1938: Frequency of days with hailstorms in India. India J. A gr. Sci., 8, 787-805,

Sansom, H. W., 1961: The occurrence of hailstorms in British East Africa. Nubila, Anno IV-M. 2, 34-51.

- 1964: The occurrence of hail in East Africa. East African Meteorological Department, Seminar on Tropical Meteorology in Africa, Document No. 27, 2-7.

Selga, M., 1929: Hail in the Philippines. Manila, Bureau of Printing, $20 \mathrm{pp}$.

Stemmler, A., and P. M. Stephenson, 1965: Heavy thunderstorm with hail at Kuching (Sarawak). Meteor. Mag., 94, 236-240.

Visher, S. S., 1922: Hail in the tropics. Bull. Amer. Meteor. Soc., 3, 117-118. 